Chapter 6

\title{
An Overview of Mud Volcanoes Associated to Gas Hydrate System
}

\author{
Umberta Tinivella and Michela Giustiniani \\ Additional information is available at the end of the chapter \\ http://dx.doi.org/10.5772/51270
}

\section{Introduction}

Humankind has been aware of volcanic activity in this planet since ancient times. This can be inferred from the remains of human settlements giving evidence of destruction by volcanic activity, and by the many myths around the world describing events that can be interpreted in relation to volcanic eruptions. Furthermore, such occurrences are evidenced by the special words that some human groups created to designate the special cases of "fire mountains", thus distinguishing these from other (non-volcanic) mountains found in the same region. More recently, as suggested by [1] Cañón-Tapia and Szakács, films and television shows devoted to exploring volcanoes have become very common, making it easier for the general public to gain access to "firsthand" experiences concerning this type of natural phenomenon. Consequently, it is only fair to say that at present almost everyone has an "intuitive" knowledge of what a volcano is [1]. In last years, many authors have devoted efforts to provide some additional theoretical aspects about volcanism, and one of the most recent publications is the book title "What is a volcano?" [1], addressing also a phylosophical question about this topic.

The definition of volcano is often missed or just defined as "opening-in-the-ground" in the textbooks. Starting from the classical Aristotelian requirements of a definition, it is shown that only a definition that is part of a hierarchically organized system of definitions can be accepted. Thus, conceptual constructs should reflect the same type of makeup as nature's processes, which are hierarchically organized. Such a line of reasoning implies that a volcano should be defined by making an explicit mention of the hierarchy of systems to which it belongs. Therefore, volcano can be defined as either a subsystem (i.e., the eruptive subsystem) of the broader igneous system or as a particular type of igneous system (i.e., one reach- 
ing the surface of Earth). A volcano, viewed as a volcanic system, is composed of a magmageneration subsystem, a magma transport subsystem, magma storage subsystem(s), and an eruptive subsystem. The accurate definition and identification of each subsystem should allow distinction between individual volcanoes in both space and time. Minimal conventional requirements need to be agreed upon by volcanologists to identify and recognize a particular volcano from other volcanoes, including those partially occupying the same space but separated in time, or those partially overlapping in both space and time. Conceptual volcanology can be envisaged as addressing the issue of accurate definition of basic terms and concepts, besides nomenclature and systematics, aiming at reaching the conceptualization level of more basic sciences. In contrast to volcanologists, sedimentologists are not only interested in "classical" volcanoes, but also in a second type, sedimentary volcanoes. This type of volcano is helpful for sedimentologists in understanding the processes that occur in the commonly unconsolidated subsoil, even after deep burial. Sedimentary volcanoes can be grouped in three classes: mud volcanoes, sand volcanoes, and associated structures such as water-escape and gas-escape structures. Sedimentary volcanoes have several characteristics in common with "classical" volcanoes, including their shapes and the processes that contribute to their genesis, as well described by [2] and here reported. These two type of volcanoes have largely similar morphologies, they overlap each other in size (large sedimentary volcanoes reach size that compete with those of many classical volcanoes), and they have a genesis that is comparable in many respect. For instance, comparison of the material flowing out from classical and sedimentary volcanoes shows that the sedimentary outflows resemble basaltic lava in the case of mud volcanoes, and acid lava in the case of sand volcanoes; this results in sedimentary volcanoes that morphologically resemble shield volcanoes and stratovolcanoes respectively.

It could be established that sedimentary volcanoes have, like the "classical" one, some kind of magma chamber in the form of a gas-and/or liquid-bearing layer with increasing pressure (either continuously, for instance, from the weight of the ever thickening sedimentary overburden, or incidentally, for instance, from an earthquake-induced shock wave). If the pressure exceeds a threshold, the pressured gas and/or liquid (commonly pore water with dissolved air or hydrocarbons) breaks upward through the overlying sediment, often following an already existing zone of weakness, to finally flow out at the sedimentary surface, either subaerially or subaqueously. In fact, the material that rises up through the connection between the source in the subsoil and the sedimentary surface behaves in several respects as magma on its journey from the magma chamber to the vent or crater opening: Magma becomes more fluid and develops gas bubbles while rising owing to decreasing pressure, and in sedimentary volcanoes with a deep-seated source the formation of bubbles also take place. These similarities should be promoted a fruitful collaboration between the researchers that can be mutually beneficial.

Among the sedimentary volcanoes, the mud volcanoes are the most interesting form many points of view, as described in this chapter. Mud volcanoes and mud volcanism are some of nature's most anonymous, mysterious and undiscussed geological features, which have 
been studied for millennia. This is strong interested and is explained considering a number of facts. First of all, thousands of mud volcanoes exist worldwide, defining and affecting the habitat and the daily lives of the millions of people living amongst them. Secondly, mud volcanism and mud volcano distribution is strongly connected to the formation and the distribution of the world's petroleum assets, thus serving as an indicator for valuable natural resources [3]. Thirdly, mud volcanoes offer an insight into otherwise hidden deep structural and diagenetic processes, such as the formation of gas hydrates, mineral dissolution and transformation, degradation of organic material and high pressure/temperature-reactions [4]. Lastly, mud volcanism generally involves voluminous generation and emission of both methane and carbon dioxide whereby most mud volcanoes serve as an efficient, natural source of greenhouse gases and, consequently, play an important role in global climate dynamics [3,5-10].

Among fluid venting structures, mud volcanoes are the most important phenomena related to natural seepage from the earth's surface [11]. Their geometry and size are variable, from one to two meters to several hundred meters in height, and they are formed as a result of the emission of argillaceous material and fluids (water, brine, gas, oil; [3,12-13]). They occur globally in terrestrial and submarine geological settings: most terrestrial mud volcanoes are located in convergent plate margin with thick sedimentary sequences within the Alpine-Himalayan, Carribean and Pacific orogenic belts [14-21]. Mud volcanoes and mud diapirs are responsible for the genesis of many chaotic deposits, such as mélanges, chaotic breccias and various deformed sediments [22-24].

The normal activity of mud volcanoes consists of gradual and progressive outflows of semiliquid material called mud breccia or diapiric mélange. Explosive and paroxysmal activities are interpreted as responsible for ejecting mud, ash, and decimetric to metric clasts. Mud volcano breccias are composed of a mud matrix, which supports a variable quantity of chaotically distributed angular to rounded rock clasts, ranging in diameter from a few millimeters to several meters [i.e., 14,18]. Clasts are of various lithologies and provenances, derived from the rocks through which the mud passed on its way to the surface or to the sea-floor. Slumps, slides and sedimentary flows can also affect the entire structure of mud volcanoes, even if gradients are very low.

The occurrence of mud volcanoes is controlled by several factors, such as tectonic activity, sedimentary loading due to rapid sedimentation, the existence of thick, fine-grained plastic sediments and continuous hydrocarbon accumulation [13,14,25-28].

A comprehensive study of submarine mud volcanoes is increasing in the last decades due to the wide use of geophysical methods, in particular side scan sonar, and the increased accuracy of the positioning of bottom samplers. Reference [12] presented an up-to-date list of known and inferred submarine mud volcanoes, describing their distribution, the mechanisms by which they form, and associated gas hydrates accumulations (Figure 1). Reference [12] clearly summarized the importance of research on submarine mud volcanoes, which is: 
1. they are a source of methane flux from lithosphere to hydrosphere and atmosphere (greenhouse effect and climatic change);

2. they may provide evidence of high petroleum potential in the deep subsurface;

3. useful data about the sedimentary section in mud volcanic areas can be determined by examination of rock fragments incorporated in mud volcanic sediments (breccia);

4. submarine mud volcanic activity may impact drilling operations, ring installations and pipeline routings;

5. gas hydrates associated with deep-water mud volcanoes are a potential energy resource.

In this Chapter, we review the mud volcanism related to gas hydrate system. It is well known that natural gas hydrate occurs worldwide in oceanic sediment of continental and insular slopes and rises of active and passive margins, in deep-water sediment of inland lakes and seas, and in polar sediment on both continents and continental shelves (Figure 2). In marine sediments, where water depths exceed about $300 \mathrm{~m}$ and bottom water temperatures approach $0^{\circ} \mathrm{C}$, gas hydrate is found at the seafloor to sediment depths of about 1100 $\mathrm{m}$. In polar continental regions, gas hydrate can be present in sediment at depths between about 150 and $2000 \mathrm{~m}$. Thus, natural gas hydrate is restricted to the shallow geosphere where its presence affects the physical and chemical properties of near-surface sediment [29].

Finally, we show an interesting case study in Antarctic Peninsula, where an important gas hydrates reservoir and mud volcanism are associated [30-32].

\section{The mud volcanoes}

Mud volcanism is not one specific process and mud volcanoes are not uniform feature settings; in fact, driving forces, activity, materials and morphologies may vary significantly [3,12-13,35-37]. About 2000 mud volcanoes have been identified in the worldwide; however, as exploration of the deep seas continues, this number is expected to increase substantially. It is estimated that the total number of submarine mud volcanoes is between 7,000 and $1,000,000[10,12]$.

The geographical distribution of mud volcanoes is strongly controlled by geological environments in which they occur, as pointed out by reference [13]. In fact, mud volcanoes are localized within the compressional zones, such as accretionary complexes, thrust and overthrust belts, forelands of Alpine orogenic structures, as well as zones of dipping noncompensating sedimentary basins, which coincide with the active plate boundaries. The few mud volcano areas out of these belts are attached to zones with high rates of recent sedimentation, such as modern fans (including underwater deltas of large rivers) or intensive development of salt diapirism. 


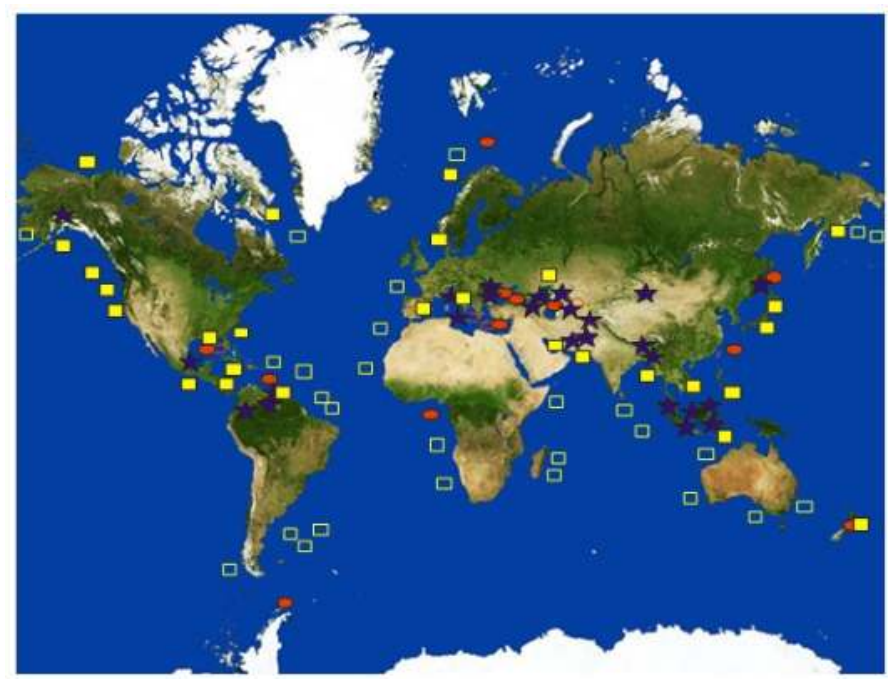

Figure 1. Map showing the worldwide locations of onshore (blue stars, after [33], with additions), known (red open oval, without gas hydrates; solid red oval hydrate bearing), and inferred (solid yellow rectangle) submarine mud volcanoes. The "possible sediment diapirs" mapped by [34] are also shown (open yellow rectangle). Modified after [12].

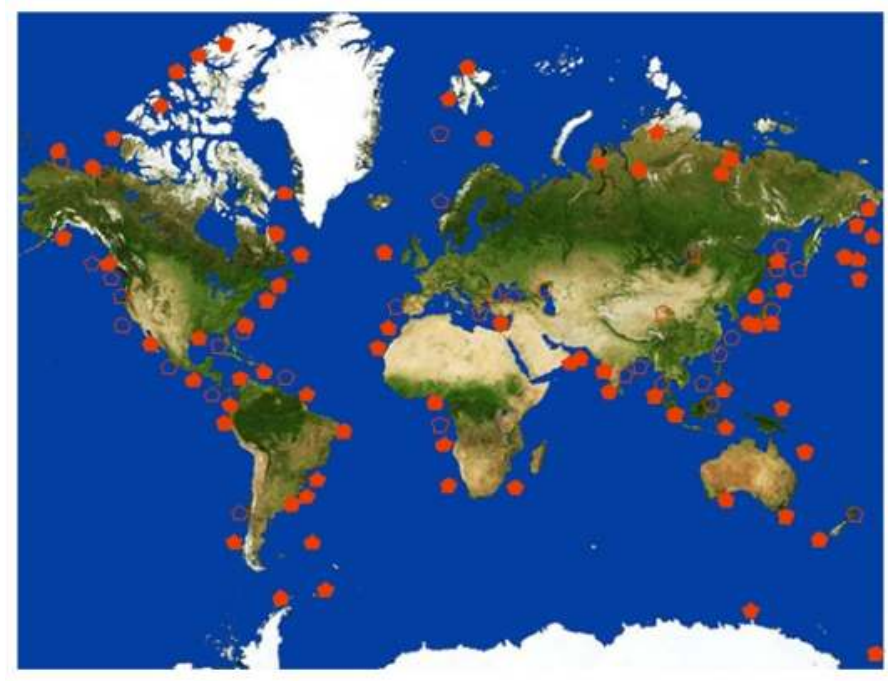

Figure 2. Map showing the worldwide locations of gas hydrate obtained by direct (open red pentagons) and indirect (solid red pentagons) measurements. Modified after [29]. 
Moreover, in all the mud volcano areas, there are suitable "source" layers of muddy sediments in the deeper part of the sedimentary basins or in the vicinity of the decolements in the accretionary complexes. Usually, this source is composed of fine-grained, soft material of low density overlain by at least $1-1.5 \mathrm{~km}$ of denser sediments. All collision complexes, where mud volcanoes are abundant, are characterized by thick sediment sequences caused by thickening of accreted sediments. The same is valid for forearc and outer orogenic basins where thickening is caused by thrusting and overthrusting. Enormous thickness is established in the noncompensating sedimentary basins.

Finally, given that the mud volcanoes are situated in areas where hydrocarbons have been, or are, actively being generated, there is a strong connection between the world mud volcano distribution and industrial oil and gas concentrations. In fact, the surrounding facies, below and laterally adjacent to mud volcanoes, may be particularly favorable as both reservoir and source environments for hydrocarbons, very often resulting in multilevel fields. Although this relationship is not valid for many mud volcano areas, for modern accretionary complexes in particular, it is established that present-day or recently active oil and especially gas generation are characteristic features for all of them.

Summarizing these brief comments the occurrence of mud volcanoes is strongly controlled by [12]:

- recent tectonic activity, particularly compressional activity;

- sedimentary or tectonic loading due to rapid sedimentation, accreting or overthrusting;

- continuous active hydrocarbon generation;

- existence of thick, fine-grained, soft, plastic sediments deep in the sedimentary succession.

Here, we summarize the main locations of the mud volcanoes as described in [12-13] and reported in Figure 1. The known or supposed mud volcanoes are irregularly clustered in separated areas forming belts, which almost totally coincide with active areas of the plate boundaries and zones of young orogenic structures. More than half mud volcanoes can be related to the Alpine-Himalaya active belt, where the largest and best cone-shaped mud volcanoes occur, as resumed in [13]. The most active terrestrial mud volcano area with the greatest number of mud volcanoes in the world is the Baku region of the Caspian Coast, Eastern Azerbaijan. Along the Alpine-Himalaya active belt, mud volcanism has been recognized in:

1. Mediterranean Ridge [28] and adjacent land areas (Sicily, Albania and Southern, Central and Northern Italy [38]),

2. the forelands of Eastern Carpathians in Romania, Kerch and Taman Peninsulas [39,40],

3. Great Caucasus [40] and the Black Sea [27],

4. the area of Southern Caspian Sea (Azerbaijan and Turkmenistan [26,41], South Caspian Basin [42], and Gorgon Plain in Iran), 
5. the Makran coast of Pakistan [43],

6. Southern Himalayas (India and China), and Burma.

Furthermore, the Alpine-Himalayas mud volcano belt continues to the south in the most NE part of Indian Ocean on and around numerous forearc islands situated along the Indonesia and Banda Arcs [22], Indonesia - Australia accretion and collision complexes [44], as well as within the Banda accretionary complex offshore [22]. The greatest number of mud volcanoes seems to be known on Timor Island at the southeast end of this belt.

The western flank of the Pacific ocean - from the Sakhalin Island/Sea of Ochotsk-area in the north via Japan, Taiwan, the Marianas, Melanesia, Samoa and Australia to New Zealand in the south - holds some 150 onshore individuals [3,7]. The total number of offshore mud volcanoes along this belt is not yet fully determined but can be expected to be even higher, while the eastern flank of the Pacific Ocean is markedly less dense in mud volcanoes. Examples are known from and around the Aleutian Trench, Alaska, British Columbia, California, Costa Rica, Ecuador and inland Peru [3,7].

In the Atlantic Ocean, several hundreds of both onshore and offshore mud volcanoes have been recognized. The vast majority is concentrated along the Caribbean thrust belts and within the Barbados accretionary complex [7], although smaller clusters/individual features have been confirmed in connection to the Amazon and the Niger deltas [7,35], along the Gulf of Cadiz [45], within the southern Canary basin [46] and offshore Portugal and Morocco in the Alboran Basin [47].

Smaller numbers of mud volcanoes have also been described from the Mississippi delta [14], Lake Michigan [3], Greenland [3], the North Sea [48], the Netherlands [49], and areas of salt diapirism, such as in the Gulf of Mexico [50], Buzachi Peninsula (North-Eastern Caspian Sea), where they are related to salt diapirism, and Alboran basin in the Western Mediterranean [47].

The main components, that contribute to mud volcanoes formation and activities, are: mud breccia, water and gas. The relative quantities and the exact qualitative properties of these components vary, depending on local geology and processes at work.

Mud breccia is basically clasts in a clay mineral-rich matrix and is what makes up most mud volcanic features. Whereas the mud typically stems from one specific carrier bed and thus is characterized by a distinct geochemical signature and clast fragments. The first reflects subsurface mud volcanic conditions and processes (clay mineral dehydration/ transformation processes), while the latter is derived from units through which the mud pass on its way to the surface and are consequently of variable lithologies, sizes (up to $5 \mathrm{~m}$ ) and shapes. Young and forceful mud volcanoes generally extrude mud breccias with a very high clast-matrix ratio (virtually clast-supported deposits), whereas the mud breccia of older mud volcanoes may be virtually clast-free with a mud content of up to $99 \%[3,13,35]$. The latter are often related to the final phase of an eruptive cycle, when loose wall rock along the conduit has already been removed by the ascending mud [3] 


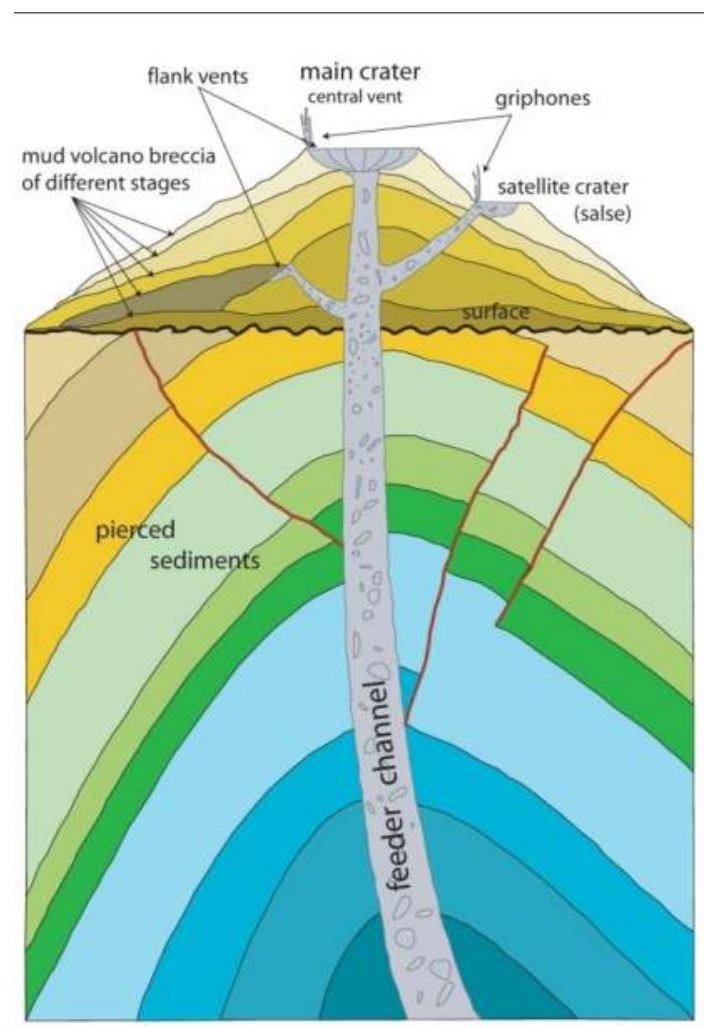

Figure 3. Basic structure and main elements of a conical mud volcano. Gryphones are small secondary vents shorter than $3 \mathrm{~m}$, which may form around the craters and in many places on the mud volcano body. These commonly emit gas, mud and water and are characterized by complete absence of solid rock fragments. Modified after [13].

The water in mud volcanic extrusions typically stems from both shallow and deep sources and is normally derived through a variety of processes. Consequently, exact geochemical properties may vary virtually indefinitely $[4,51]$. However, clay mineral-dehydration water often makes up a significant proportion [3]. Mud breccia and mud volcanic water commonly mix whereby mud volcanic flows of different viscosities may form. During fierceful mud volcanic eruptions, up to 5 million cubic metres of such flow-material can be expelled [35].

Methane is almost always the dominated gas (70 - 99\%) produced and emitted through mud volcanism. Moreover, since most mud volcanoes are very deeply rooted, thermogenic, 14Cdepleted (fossil) methane is more common than biogenic [3,10,52]. Remainders typically include (in falling order) carbon dioxide, nitrogen, hydrogen sulfide, argon and helium $[10,13,37]$.

As clearly explained in [13], a mud volcano comprises two main morphological elements: an internal feeder system and an external edifice (Figure 3). The characteristics of these ele- 
ments are highly dependent on prevailing mud volcanic processes and in some cases, vice versa. Usually, mud volcano breccia is extruded from one major funnel called central or feeder channel (as summarized in Figure 3). Near the surface, several accompanying smaller flank or lateral pipes may split off the feeder channel. The outcrop of the feeder channel (usually situated on the summit of mud volcano) is called the main vent or central crater being of varied shapes: from planoconvex or flat and bulging plateau circled by a bank to deeply sunk rim depression (a caldera-type crater). Calderas form when a volcano collapses because a large mass of mud volcano breccia has drained through a lower vent, or because of the expulsion of a massive amount of material in an explosive eruption. Such eruptions have been known to destroy the entire structure of a volcano. Craters associated with the lateral vents are called satellite, parasite or secondary craters (Figure 3). Sometimes they collapse and are filled up by water that collects to form small lakes. Such a pool bubbling clay and gas is called salses. Numerous small secondary vents called gryphons may form around the craters and in many places on the mud volcano body. These commonly emit gas, mud and water and are characterized by complete absence of solid rock fragments. Although the numerous visual observations show that the gas seeps are very common on submarine mud volcanoes [53-55], the migrated gas is often captured in the near bottom sediments as gas hydrate [12,56-58] or trapped in shallow reservoirs to erupt when overpressured to form pockmarks on the seafloor [59]. The extruded mud volcano breccia spills in relatively thin sheets from the craters over the landscape in the form of broad fan-shaped or tongue-like flows up to several hundred meters wide and some kilometers long, as explained in reference [41]. This builds up the body of the mud volcano, typically covering some thousands of square meters with each phase of activity, totaling up to few tens of square kilometers. The fluid behavior of the mud volcano breccia is attributed to its high water content, which on land rapidly evaporates to drain the mud over a period of several days. Slumps and slides often form on the entire structure of the mud volcanoes even in very low gradients.

The internal feeder systems of mud volcanoes are not well known. Although studies imply rather large variabilities, typically, they consist of one main, central and deeply (km-scale) rooted feeder channel through which most mud volcanic material is transported. Feeder channels can be everything from cylindrical to irregular shaped to mere slits [3]. Near the surface, feeder channels tend to thin off and split into smaller flanking/lateral pipes [21]. The diameters of volcanic conduits may have a profound impact on mud volcanic activity. Generally, the wider is the conduit, the more voluminous is the expulsions [3].

The external morphology and expression of a mud volcano may vary almost indefinitely. The outcrops (vents/craters) of feeder channels may take on a variety of shapes; from planoconvex or flat and bulging to concave collapse structures of caldera-type [13]. Some mud volcanoes are in fact rather anonymous and quiescent features appearing merely as solitary, mm-scale openings in the ground surface, gently seeping small amounts of high-viscosity mud breccias and/or gas [14,35]. However, some mud volcanoes are really hazardous and expel voluminous amounts of low-viscosity mud-flows through frequent, short but fierce and explosive eruptions. This type of mud volcanoes typically evolve into kilometre-scale, chaotic and complex landscapes that comprise anything from clusters of cone-shaped mor- 
phologies rising hundreds of meters above ground to mounds, ravines, pools of bubbling mud and/or water (salses), mud cracks and clastic lobes [14,37,60]. During and following this type of active, hazardous mud volcanism, combustion of emitted gases may produce columns of flames rising up to several hundreds of meters, potentially burning for months or even years [37].

Mud volcanism and mud volcanoes have repeatedly been suggested to be a natural way of degassing the Earth's interior [13,61-63]. Although mud volcanism typically does involve thermogenic formation and expulsion of gas (a natural process which to a certain extent independently would be able to force deeply buried material to the surface), such processes can hardly serve to explain the truly vast extent and scope of worldwide mud volcanism. As resumed by [35], based on the large differences observed in shape, size and eruption styles of mud volcanoes, it is clear that there is no unique model that can explain them all. Ultimately, mud volcanoes form either as clay diapirs that reach and pierce the ground-surface or as fluidized argillaceous sediments, together with water and various amounts of hydrocarbon gases, which are extruded along structural weaknesses (conduits) within subsurface sediments/rocks [12].

Either way, a fundamental requisite for mud volcanism is the existence of a potential source domain; solitary or interconnected argillaceous carrier beds for migrating fluids and gases. Yet, for the actual volcanic processes to commence and continue - for gases to form and/or for the source material to move, rise and eventually extrude from the subsurface - additional forces are needed.

Since a vast majority of the mud volcanoes that are known today exist along active plate boundaries and, more specifically, along the anticlinal crests of accretionary prisms (the major depositional centres), compression through convergent tectonics and associated high sediment accumulation rates are generally considered the major mechanisms of mud volcanic initiation and sustenance. Argillaceous sediments and rocks are typically very weak and therefore, under the influence of compressive forces, prone to various clay mineral alteration and dehydration processes [4] and to brittle deformation through e.g. faulting. Moreover, under these very conditions, thermal and/or biogenic formation of hydrocarbon gases typically increases. Together, this implies formation of potential volcanic conduits, liquefaction, fluidization, gasification, density inversion, pore pressure increase and focused migration of mud volcanic material - i.e. mud volcanism - either through diapirism or along newly created faults/conduits [3,13-14,35].

Finally, the same forces and processes may explain mud volcano formation along passive continental margins. Although tectonic forces are lacking in such settings, compression, fluidization, gasification, overpressuring and mud volcanism may take place due to loading through rapid deposition of large amounts of (argillaceous) sediments [12,35]. A common characteristic for regions of mud volcanism located outside convergent plate boundaries is that mud volcanoes measure greatly in the vertical section (at least $2 \mathrm{~km}$ ) and that they are a compound of undercompacted sedimentary sequences [7]. Consequently, although local settings may vary, the main mechanism of formation for mud volcanoes and mud volcanism is compression - ei- 
ther through tectonic forces or through high sediment accumulation rates - eventually leading to overpressuring through in situ gas generation, fluidization and liquefaction.

The fact that most mud volcanoes present regular, distinct seasonal changes in activity on a range from weeks to tens of years suggests an influence of more than one external agent, initiating and sustaining some kind of continuous, cyclic, natural pressure-recharging process within the mud volcanoes themselves. Astronomical cycles - e.g. orbital forcing - undoubtedly serve as one explanation. Through altering atmospherical and hydrospherical PTconditions over a great variety of time-scales, such cycles may also affect and alter PTconditions in the sediments and thereby mud volcanic processes via e.g. fluid access and bacterial activity (gas formation; [6]). As an example, after studying mud volcanism in the south Caspian Basin, reference [37] concluded that as much as $60 \%$ of all eruptions took place during either new or full moon. Moreover, reference [35] suggested a relationship between an 11- year cycle of the sun's activity and the initiation of mud volcano eruptions.

Even though astronomical cycles may explain most of the steady variations in mud volcanic eruption frequencies, they do not explain the rather frequent, more irregular eruptions. These are rather a result of ample, sudden seismic activity. If earthquake hypocenters are located within/in connection to potential carrier beds, shaking of the sediments may induce liquefaction and faulting as well as a significant increase in gas formation and dissociation. Consequently, rather sudden, eruptive mud volcanism may be generated in a normally quiescent or even dormant mud volcanic area [3,13,37,64].

Mud volcanoes can be related also to volcanic basins, which are sedimentary basins with a significant amount of primary volcanic rocks (e.g. sills and dykes). Pierced basins are sedimentary basins with many piercement structures such as mud volcanoes, dewatering pipes and hydrothermal vent complexes. Sills are tabular igneous intrusions that are dominantly layer parallel. They are commonly subhorizontal. Sills may locally have transgressive segments (i.e. segments that cross-cut the stratigraphy). Hydrothermal vent complexes are pipe-like structures formed by fracturing, transport and eruption of hydrothermal fluids. These complexes are dominated by sedimentary rocks with a negligible content of igneous material. Sediment volcanism is surface eruption of mud, sand or sediment breccias through a vent complex [65].

Hydrothermal and phreatomagmatic vent complexes are recognized from several sedimentary basins associated with large igneous provinces, including the Vøring and Møre basins off mid-Norway [66-68], the Faeroe-Shetland Basin [e-g- 69], the Karoo Basin in southern Africa [e.g. 70-75], in the Karoo-equivalent basins of Antarctica [76-78], and the Tunguska Basin in Siberia, Russia [e.g. 79]. Generally, the hydrothermal vent complexes represent conduit zones up to $8 \mathrm{~km}$ long rooted in contact aureoles around sill intrusions, where the upper part of the vent complexes comprise eyes, craters or mounds, up to $10 \mathrm{~km}$ in diameter [68]. An important consequence of intrusive activity in sedimentary basins is that the magma causes rapid heating of the intruded sediments and their pore fluids, causing expansion and boiling of the pore fluid [75], and metamorphic dehydration reactions. These processes may lead to phreatic volcanic activity by the formation of cylindrical conduits that pierce sedimentary strata all the way to the surface. The hydrothermal vent complexes thus repre- 
sent pathways for gases produced in contact aureoles to the atmosphere, with the potential to induce global climate changes [80]. Consequently, constraints on processes leading to the formation of hydrothermal vent complexes in sedimentary basins, their abundance and structure may lead to a better understanding of the causes of the abrupt climate changes that are associated with many large igneous provinces [e.g. 81, 82]. References [65, 83] have analyzed the presence of voluminous basaltic intrusive complexes, extrusive lava sequences and hydrothermal vent complexes in the Karoo basin. In this area, the hydrothermal vents pierce the horizontally stratified sediments of the basin. They study have documented that the hydrothermal vent complexes were formed by one or a few phreatic events, leading to the collapse of the surrounding sedimentary strata. They proposed a model in which hydrothermal vent complexes originate in contact metamorphic aureoles around sill intrusions. Heating and expansion of host rock pore fluids resulted in rapid pore pressure build-up and phreatic eruptions. The hydrothermal vent complexes represent conduits for gases and fluids produced in contact metamorphic aureoles, slightly predating the onset of the main phase of flood volcanism.

Reference [84] investigated and understood the mechanisms responsible for the formation of piercement structures in sedimentary basins and the role of strike-slip faulting as a triggering mechanism for fluidization. For this purpose four different approaches were combined: fieldwork, analogue experiments, and mathematical modeling for brittle and ductile rheologies. The results of this study may be applied to several geological settings, including the newly formed Lusi mud volcano in Indonesia [84], which became active the 29th of May 2006. Their integrated study demonstrates that the critical fluid pressure required to induce sediment deformation and fluidization is dramatically reduced when strike-slip faulting is active. The proposed shear-induced fluidization mechanism explains why piercement structures such as mud volcanoes are often located along fault zones. Their results support a scenario where the strike-slip movement of the Watukosek fault triggered the Lusi eruption and synchronous seep activity witnessed at other mud volcanoes along the same fault. The possibility that a drilling, carried out in the same area, contributed to trigger the eruption cannot be excluded. However, so far, no univocal data support the drilling hypothesis, and a blow-out scenario can neither explain the dramatic changes that affected the plumbing system of numerous seep systems on Java after the 27-05-2006 earthquake. Reference [85] have combined satellite images with fieldwork and extensive sampling of water and gas at seeping gryphones, pools and salsa lakes at the Dashgil mud volcano in Azerbaijan in order to investigate the fluid-rock interactions within the mud volcano conduit. The gas geochemistry suggested that the gases migrate to the surface from continuously leaking deep seated reservoirs underneath the mud volcano, with minimal oxidation during migration. However, variations in gas wetness can be ascribed to molecular fractionation during the gas rise. In contrast, the water shows seasonal variations in isotopic composition and surface evaporation is proposed as a mechanism to explain high water salinities in salsa lakes. By contrast, gryphones have geochemical signals suggesting a deep-seated water source. This study has demonstrated that the plumbing system of dormant mud volcanoes is continuously recharged from deeper sedimentary reservoirs and that a branched system of conduits exists in the shallow subsurface. While the gas composition is consistently similar throughout the 
crater, the large assortment of water present reflects the type of seep (i.e. gryphones versus pools and salsa lakes) and their location within the volcano.

In last decade, many researchers conducted in Karoo have pointed out an interesting link between hydrothermal venting (potential sand/mud volcanoes on the surface) and maar-diatreme volcanism (eg. magma - water interaction driven explosive volcanism). The hydrothermal vent complexes identified in this area have previously been termed diatremes and volcanic necks, and have, since the pioneer work of references [70,71], been interpreted as the result of phreatic or phreatomagmatic activity [e.g. 72,74,86-90]. Some hydrothermal vent complexes are spatially associated with sill intrusions, but a direct relationship between conduit zones and contact aureoles cannot be demonstrated because of lack of exposures and boreholes. A general genetic relationship between sills and vent complexes is, however, supported by interpretations of seismic data from the Vøring and Møre basins of offshore mid-Norway, where it is shown that hydrothermal vent complexes are rooted in aureole segments of sill intrusions $[68,75]$. The general lack of igneous material in the hydrothermal vent complexes strongly suggests that they are rooted in a zone without major magma disintegration. Reference [65] have recently proposed a model of vent complex formation by heating and boiling of pore fluids in contact aureoles around shallow sills [75]. In this model, boiling of pore fluids may occur at depths as great as c. $1 \mathrm{~km}$, and overpressure and possibly venting occur if the local permeability is low. Thick sills are common in the Stormberg Group sediments, at least in the Molteno Formation, which can be assumed to have caused shallow $(1 \mathrm{~km})$ boiling and expansion of pore fluids in contact aureoles. A high-permeability host rock requires a very rapid pressure build-up compared with permeability to initiate hydrofracturing. Following hydrofracturing, the gas phase may expand and lead to a velocity increase during vertical flow through the conduit zone. Thus, the vent formation mechanism bears resemblance to shallow breccia-forming processes in hydrothermal and volcanic systems [e-g- 76,91,92].

In systems dominated by fragmentation of magma (e.g. kimberlite pipes and diatremes), the resulting conduit zone will comprise mixtures of sediments and igneous material, and associated surface deposits dominated by pyroclastic material [e.g. 91-94]. Kimberlite pipes are generally formed from fragmentation of deep dyke complexes [e.g. 92,93], and this mechanism may also explain the formation of the phreatomagmatic complexes in the Karoo Basin [e.g. 95,96]. As very well explained by [97], kimberlitic diatremes are the most important economically, but despite decades of research, numerous open pit and underground mines, and hundreds of kilometers of diamond drilling, they remain poorly understood in volcanological terms, with multiple and strongly conflicting models in place. Reference [97] attempted an evenhanded review of maar diatreme volcanology that extends from mafic to kimberlitic varieties, and from historical maar eruptions to deeply eroded or mined diatreme structures.concentrated their study to convinced that increased understanding of other maar-diatremes will drive advances in kimberlite volcanology, and is best accomplished by integrating information from all parts of all types of maar-diatreme volcanoes, and from both subsurface and surface observations. 
Finally, it is important to mention that several study [i.e. 98,99] have highlighted the importance of the emplacement environment of volcanism in causing global environmental climate changes. They suggested that an understanding of the triggering mechanism and consequences of previous climatic changes driven by carbon gas emissions is highly relevant for predicting the consequences of current anthropogenic carbon emissions, as these events are likely of similar magnitude and duration.

\section{The gas hydrates}

Natural gas hydrates are a curious kind of chemical compound called a clathrate. Clathrates consist of two dissimilar molecules mechanically intermingled but not truly chemically bonded. Instead one molecule forms a framework that traps the other molecule. Natural gas hydrates can be considered modified ice structures enclosing methane and other hydrocarbons, but they can melt at temperatures well above normal ice [i.e., 100]. At about $3 \mathrm{MPa}$ pressure, methane hydrate begins to be stable at temperatures above $0{ }^{\circ} \mathrm{C}$ and at about 10 MPa it is stable at $15{ }^{\circ} \mathrm{C}$ [101]. This behavior has two important practical implications. First, it is a nuisance to the gas company. They have to dehydrate natural gas thoroughly to prevent the formation of methane hydrates in high pressure gas lines. Second, methane hydrates will be stable on the sea floor at depths below a few hundred meters and will be solid within sea floor sediments [102]. Masses of methane hydrate "yellow ice" have been photographed on the sea floor. Chunks occasionally break loose and float to the surface, where they are unstable and effervesce as they decompose.
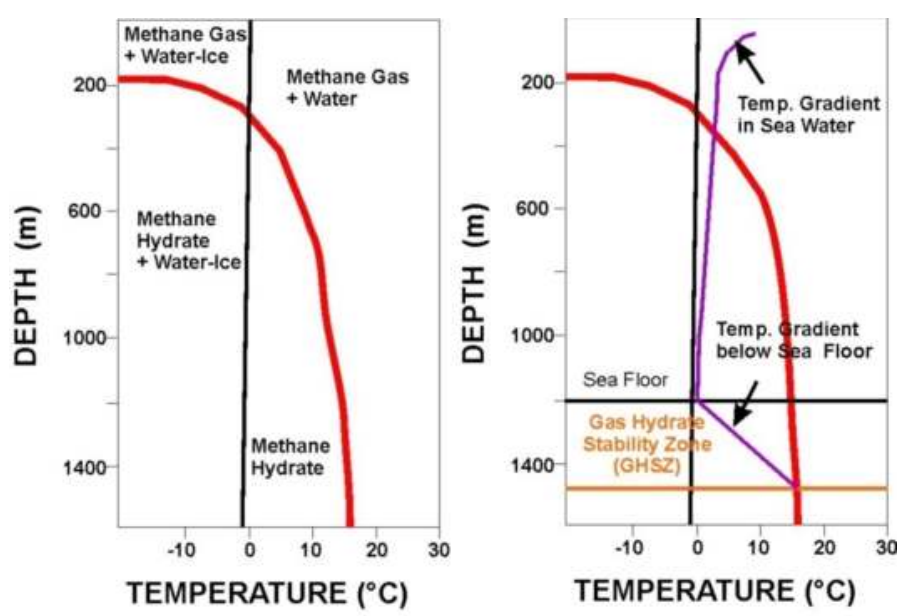

Figure 4. Left: Methane hydrate phases. Right: Typical occurrence of the gas hydrate stability zone on continental margins. A water depth of 1,200 $\mathrm{m}$ is assumed. The viola line represents the geothermal curve, while the red line is the gas hydrate stability curve. The orange line is the base of gas hydrate stability zone (GHSZ). 
Figure 4 shows the combination of temperatures and pressures (the phase boundary) that marks the transition from a system of co-existing free methane gas and water/ice solid methane hydrate, which forms at low temperature and relative high pressure. When conditions move to the left across the boundary, hydrate formation will occur. Moving to the right across the boundary results in the dissociation of the gas hydrate, releasing free water and methane.

The phase diagram reported in Figure 4 shows a typical situation on continental shelves. Assuming a seafloor depth of 1,200 m, temperature steadily decreases with water depth, and a minimum value near $0^{\circ} \mathrm{C}$ is reached at the ocean bottom. Below the sea floor, temperatures steadily increase, so the top of the gas hydrate stability zone (GHSZ) occurs at roughly 400 $\mathrm{m}$, while the base of the GHSZ is at 1,500 m. From the phase diagram, it appears that hydrates should accumulate anywhere in the ocean-bottom sediments where water depth exceeds about $400 \mathrm{~m}$. Very deep (abyssal) sediments are generally not thought to house hydrates in large quantities. In fact deep oceans lack both the high biologic productivity (necessary to produce the organic matter that is converted to methane) and rapid sedimentation rates (necessary to bury the organic matter) that support hydrate formation on the continental shelves. Note that the conditions for gas hydrate formations are present also in sea water, but gas concentration is always not sufficient for their formations.

The gas hydrate phase is affected by gas mixture and pore-fluids composition (salinity). It is known that the presence of only a small percentage of higher hydrocarbons (such as ethane and propane) shifts the phase boundary to higher temperature (at constant pressure). The effect is that the base of GHSZ is shifted to greater depths [100,103]. Analogous to the effect of salt on the freezing point of water, if pore-fluids composition is brine, the phase boundary is shifted to lower temperatures at a given pressure and thus base of GHSZ will be shallower, as demonstrated by different authors [i.e., 204. Figure 5] shows a comparison among several gas hydrate stability models proposed in literature. The black line indicates the methane hydrate stability in brine water with a salinity of $3.5 \%$ [105]. The red lines are evaluated by using the equations reported in [100] which consider fresh water. The solid red line indicates the methane hydrate stability curve and the dashed red line the hydrate stability curve considering a mixture of methane $(90 \%)$, ethane $(5 \%)$ and propane $(5 \%)$. The blue lines are the hydrate stability in fresh water considering pure methane (solid line) and a mixture of methane $(90 \%)$ and ethane $(10 \%)$ by using the empirical expression proposed by [106]. Reference [107] obtained empirical equation for methane hydrate system in function of salinity. The green lines represent the gas hydrate stability considering the following salinity values: $0.0 \%$ ( i.e. fresh water; solid line), $2 \%$ (dotted line), $3.5 \%$ (dashed line), and $5 \%$ (dashed-dotted line). Finally, the magenta line indicates the stability for system of pure methane and water, following the approach of Reference [108]. Note that the methane hydrate stability curves in fresh water obtained from the proposed models are almost coincident, while the case considering salt water shows differences between the considered approaches.

The stability of methane hydrates on the sea floor has several implications [i.e., 109,110]. First, they may constitute a huge energy resource [111]. Second, natural and man-made disturbances may cause their destabilization causing the release of huge amounts of fluids (gas and water) and affecting slope stability. Finally, methane is an effective greenhouse gas (26 
times more powerful than carbone dioxide), and large methane releases may explain sudden episodes of climatic warming in the geologic past. Some authors suggested that gas hydrate dissociation influenced significantly climate changes in the late Quaternary period [112-115]. The Clathrate Gun Hypothesis [116] suggests that past increases in water temperatures near the seafloor may have induced such a large-scale dissociation, with the methane spike and isotopic anomalies reflected in polar ice cores and in benthic foraminifera [115]. Reference [117] suggested that methane would oxidize fairly quickly in the atmosphere, but could cause enough warming that other mechanisms (for example, release of carbon dioxide from carbonate rocks and decaying biomass) could keep the temperatures elevated.

Gas hydrates in marine environments have been mostly detected from analysis of seismic reflection profiles, where they produce remarkable bottom-simulating reflectors (BSRs; $[100,118])$. Generally, the BSR is a very high-amplitude reflector that is associated with a phase reversal that approximately parallels the seafloor [119]. This phase reversal, which results from a strong acoustic impedance contrast between the layers, may indicate that sediments above the BSR are extensively filled with gas hydrates and sediments below it are filled with free gas in the pore space [i.e., 120-122]. Because the BSR follows a thermobaric surface rather than a structural or stratigraphic interface, it is normally observed to crosscut other reflectors [123].

Several studies [i.e. 30] revealed a seismic reflector below the BSR that can be associated with the base of the free gas zone, called base of the free gas reflector (BGR). The scientific community have been devoted much effort in studying marine sediments containing gas hydrates to characterize the hydrate reservoir and to quantify the gas trapped within sediments from seismic data analysis [i.e., 31,122,124,125]. To reach this goal advanced techniques have been developed. In fact, the BSR, detected from seismic data, is an easily recognizable indicator of the presence of hydrate, but it does not provide information directly on the concentration of hydrate and free gas or their distribution. One approach to estimate hydrate and free gas concentration is from seismic velocity (primarily P-wave velocity, $\mathrm{Vp}$ ), obtained through advanced seismic analysis and/or modeling of data from a multichannel seismic streamer, using techniques such as common-image gathers analysis [i.e., 32], one dimensional waveform inversion [i.e., 126], and amplitude versus offset analysis [i.e., 127]. The obtained velocity can be translated in terms of concentration by using theoretical models [i.e., 127,128]. Figure 6 reports an example of compressional and the shear (Vs) velocity versus gas hydrate and free gas saturation in pore space by using two models: the Biot theory [129] and the approximation for seismic frequency [128]. Note that in presence of high hydrate concentration, the velocity increases significantly, while, if we suppose uniform distribution of free gas in the pore space, it is sufficient a small content of free gas to reduce drastically the velocity.

Recently, the international community has considered $\mathrm{CO}_{2}$ sequestration as a possible means of offsetting the emission of greenhouse gases into the atmosphere [130]. Some studies have considered confining $\mathrm{CO}_{2}$ hydrate directly to shallow sediments on the deep sea floor, but this approach would not be permissible under the above international conventions. In the case of hydrates, several studies have investigated the use of injected $\mathrm{CO}_{2}$ to lib- 
erate methane gas from hydrate in sediments, and in the process lock up $\mathrm{CO}_{2}$ in $\mathrm{CO}_{2}$ hydrate [i.e., 131]. The $\mathrm{CO}_{2}$ storage program is a further reason to assess the feasibility of mapping and monitoring the reservoir by means of an efficient seismic analysis $[132,133]$ and to obtain information about hydrate and free gas concentrations in a time-effective way.

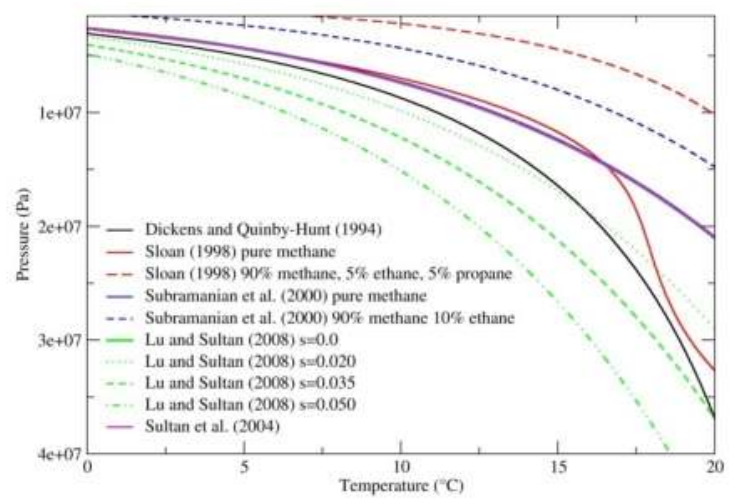

Figure 5. Comparison among different gas hydrate stability models. See text for details.
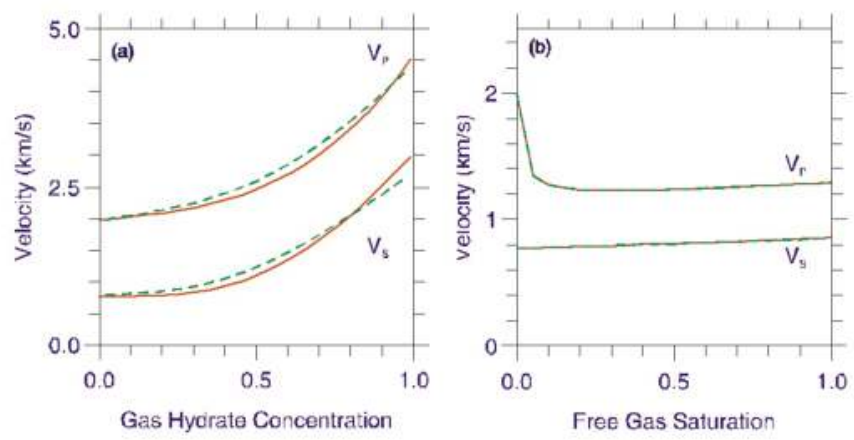

Figure 6. Comparison between two models: the Biot theory (solid red lines; [129]) and the approximation for seismic frequency (green dashed lines; [128]). (a) Compressional (Vp) and shear (Vs) velocity versus gas hydrate concentration in pore space. (b) Vp and Vs versus free gas saturation in pore space, supposing uniform distribution.

Finally, it is worth to mention that gas hydrates cannot survive for long geological times either because buried sediments are submitted to increasing geothermal conditions or are tectonically uplifted. In fossil sediments, the study of the interaction between seep-carbonates, hydrate destabilization and sediment instability is particularly difficult, owing to the lack of 
a direct recognition of fluid seepages and to the absence of precise quantifications of paleoenvironmental factors (pressure, temperature, paleodepth) conditioning hydrate stability conditions [134]. Following present-day analogues, the only means to infer a possible role of gas hydrates in fossil seep-carbonates are geochemical (oxygen isotope signature) and textural (presence of distinctive sedimentary features such as breccias, pervasive non-systematic fractures, soft sediment deformation) described in clathrites. Additional evidences can derive from the close association between seep-carbonates and sedimentary instability, and the large dimensions of seep-carbonate masses bearing brecciated structures. Recently, [134] studied cold seep-carbonates and associated lithologies in the northern Apennines and highlighted the seepage activity and the possible relationships with gas hydrate destabilization. In this geological context, many seep-carbonates are characterized by negative $\partial 13 \mathrm{C}$ and positive $\partial 18 \mathrm{O}$ values, by various types of brecciated structures and fluid-flow conduits, and are associated with intense sediment instability such as slumps, intraformational breccias and olistostromes.

Many authors have focused their attention on the possible modes of gas hydrate formations. Here, we report the study proposed by [135], which clearly summarized the possible mode of gas hydrate formation and produced a cartoon of gas hydrate system (Figure 7). They envisioned three possible modes of hydrate formation.

First, dipping permeable layers may focus gas flow and drive large amounts of free gas into the regional gas hydrate stability zone (Figure 7, number 1, inset). This is illustrated with a dipping stratigraphic layer in Figure 7; however, the permeability conduit could also be a fault or fracture. Beneath the GHSZ, the permeable layer draws gas from the surrounding material over an extensive source region, because of its high permeability and resultant low capillary entry pressure [136]. In this environment, gas rapidly enters the GHSZ and salinity rises as hydrate forms. The increased salinity inhibits further hydrate formation, which allows free gas to coexist with hydrate within the GHSZ. This process is repeated and the gas chimney rapidly propagates to the seafloor. Within the chimney, hydrate concentration increases upward toward the seafloor, where the system is furthest from equilibrium (Figure 7 , number 1, inset). At the base of the gas chimney, the BSR will be diminished because gas is continuously present across the base of the GHSZ. These types of gas chimneys may be present, for example, at South Hydrate Ridge [109,137,138], at Blake Ridge [139-142] and along the Norwegian margin $[143,144]$.

A second form of focused gas flow is illustrated in Figure 7 (number 2, inset). In this case, gas concentrates beneath the topographic crest of the seafloor structure. On the flanks of the structure, gas is trapped beneath the low-permeability base of the hydrate stability zone. Buoyancy drives the gas laterally toward the shallowest zone beneath the regional hydrate stability zone. The gas pressure is at a maximum at this location and ultimately the gas will drive its way through the GHSZ creating a gas chimney. As illustrated, the gas vent does not penetrate to the seafloor.

At the flanks of the topographic structures, a low permeability hydrate seal rapidly develops at the base of the GHSZ as illustrated in case 3 (Figure 7, number 3, inset). Hydrates are formed when water flows up through the GHSZ. Even in this low-flux example, 
the gas supply is large enough to create a separate gas phase that migrates upward by buoyancy. The changes in salinity during hydrate formation are too small for a three-phase zone to develop, and hence all free gas is crystallized as hydrate at the base of the GHSZ (Figure 7, number 3, inset). As hydrate forms, the permeability drops and a capillary seal to gas is formed. In these circumstances, either the gas pressure will build until it fractures the overlying column, or if there is another pathway present, the gas will flow upward but underneath the low-permeability cap of the base of the GHSZ (Figure 7). Finally, far from where any methane gas flow is focused but where there is upward flow of water, low concentrations of hydrate may be deposited within the RHSZ but not at its base (Figure 7, number 4, inset).

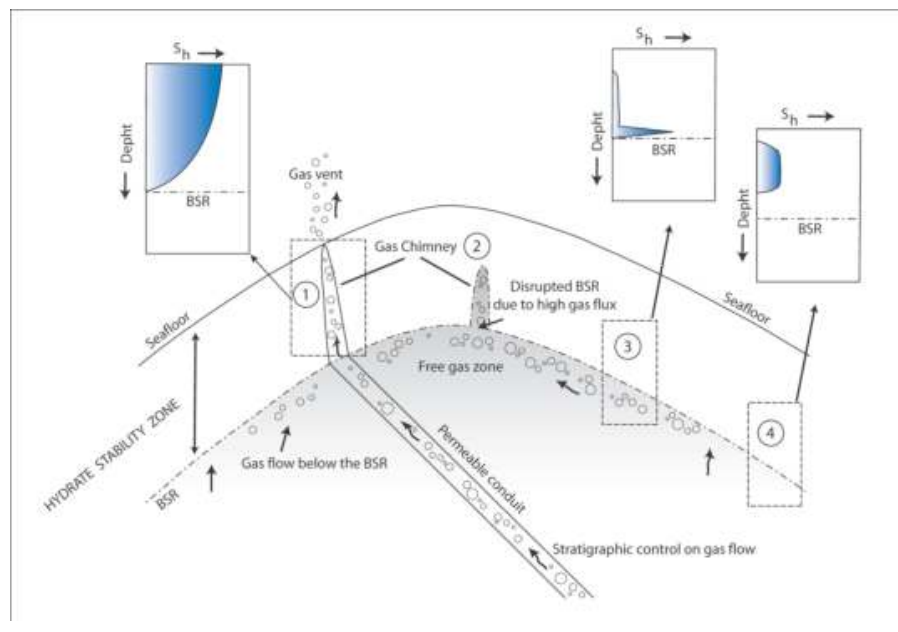

Figure 7. Cartoon of the gas hydrate reservoir system. Four characteristic forms of hydrate deposit are shown. (1) Gas chimney sourced by permeable conduits. Gas is focused along permeable conduits beneath the hydrate stability zone. Focused flow penetrates the GHSZ and self-generates a three-phase pathway to vent gas to the seafloor. (2) Gas chimney sourced by gas trapped beneath the GHSZ. Gas is focused along the base of the GHSZ and trapped beneath the crest of the structure. Gas builds up until it begins to form a chimney through the GHSZ. (3) Capillary sealing and lateral migration. On the flanks of the structure, hydrate formation rapidly forms capillary seals to gas and the gas is driven laterally to the highest structural point. (4) Aqueous flow and hydrate formation. Far from the crest, water with dissolved methane migrates upward and deposits hydrate within the GHSZ. Modified after [109].

The simulations of [109] provide insight into how gas chimneys form and sustain themselves within the GHSZ. The penetration of gas into the GHSZ is controlled by a competition between the basal supply of gas and the lateral diffusion of salt. The gas flow is driven primarily by buoyancy: as a result, the natural tendency for gas is to flow vertically even when permeability is reduced by hydrate formation. In addition, salt diffusivity is extremely low; thus high salinity zones within chimneys can be maintained for long times, particularly if there is continued supply of gas to form more hydrate and maintain salinity. Finally, lateral salt diffusion concentrates hydrate at the margins of the chimney; this further lowers the salt diffusivity and further limits salt loss. 
Reference [135] showed that at South Hydrate Ridge, gas is supplied at a rate 10 times greater than is depleted by hydrate formation due to salt diffusion. Salt loss by diffusion, and hence the amount of methane needed to form hydrate to replace the salt, is independent of the vent half-width. In general, if the flux of methane supplied is greater than the loss due to diffusion, a chimney will be created and maintained at three-phase equilibrium (Figure 7, number 1, inset). However if the gas flux supplied is less than the loss due to diffusion, the chimney will only penetrate a short distance within GHSZ and free gas will not reach the seafloor (Figure 7, number 2, inset).

\section{The gas hydrate in submarine mud volcanoes}

The jointly occurrence of submarine mud volcanoes and gas hydrate has been reported by many authors in world-wide [i.e. 26,42,145-148]. For example, on the upper continental slope of the Gulf of Mexico, active gas migrations along faults or at mud volcanoes have been identified and their sources attributed to accumulated gas hydrates [53,149]. Reference [12] estimated that methane accumulated in gas hydrate associated with mud volcanoes is about $10^{10} \sim 10^{12} \mathrm{~m}^{3}$ at normal temperature and pressure. Reference [150] estimated that up to $40 \%$ of total United Kingdom methane emission was from the continental shelf around UK. It is therefore important to investigate marine gassy sediments and submarine mud volcanoes to better understand the dynamics of shallow-water methane transport, fluid migration and the relationship of these phenomena to gas hydrate.

Firstly, we recall an important review of submarine mud volcanoes reported in Reference [12], reporting the main points. Evidence for submarine mud volcanoes exists in many regions showing the following features:

1. subcircular structures up to several kilometers in diameter elevated above the surrounding seafloor and visible on bathymetric maps and/or sonar images;

2. seafloor-piercing shale diapirs visible on seismic profiles;

3. fluid expulsion above elevated seafloor structures revealed by acoustic profiles and through visual observations from a submersible, remote operated vehicle (ROV), or by underwater video-camera;

4. transient mud islands in shallow waters;

5. gas bubbles at the surface of water that may be related to mud volcanoes.

Submarine mud volcanoes occur world-wide on continental shelves, slopes and in the abyssal parts of inland seas. Some studies (i.e. from the Barbados accretionary complex [54,151]) have linked the morphology of submarine mud volcanoes to different development stages and processes of mud liquefaction. Conical-shaped mud volcanoes ('mud-mounds' or gryphons), which do not have any central summit 'mud lakes' (or salses), are formed by the expulsion of plastic mud breccia in concentric radial flows. In contrast, shearing with the feeder conduit liquefies the mud leading to the formation of flat-top mud volcanoes (mud- 
pies) with central 'mud lakes' and elongated, radial mud-flow tongues. In both types, the mud is found to have a plastic behavior in which its yield strength decreases with increasing porosity. Thixotropy is associated with high porosity (e.g. more than $70 \%$ ), which is often related to the dissociation of gas hydrate [151]. Often, mud volcanoes are associated with methane fluxes, either as free gas or, depending on ambient temperature and pressure conditions, as gas hydrate [54,152]. On this basis, Reference [14] argue that the global flux of methane to the atmosphere from the world's terrestrial and submarine mud volcanoes is highly significant. The relative difficulty in studying submarine mud volcanoes, compared with their terrestrial counterparts, leaves substantial gaps in our knowledge about their modes of formation, the duration and frequency of eruptions and the fluxes of mud and volatile phases from the subsurface. For this reason, several efforts are spend to simulate numerically the formation of submarine mud volcanoes [i.e., 153].

At the present time, evidence for submarine mud volcanoes has been found in all oceans (Figure 1). For instance, in shallow water areas (shelves) where mud islands are recorded, submarine mud volcanoes are likely to be present. However, there are regions where the existence of submarine mud volcanoes is unexpected, such as in the Baltic Sea, where sediments are only $10 \mathrm{~m}$ thick, but miniature mud diapirs/volcanoes $(1.5 \mathrm{~m}$ in diameter, $30 \mathrm{~cm}$ high above the surrounding seafloor) are reported [154,155]. Figure 1 includes sediment diapirs reported in [33]; however, it is unclear whether all these sediment diapirs are mud volcanoes. Submarine mud volcanoes are more extensive than their sub-aerial analogs.

All the regions where submarine mud volcanoes or evidence for them have been observed are confined to shelves, continental and insular slopes, and abyssal parts of inland seas (e.g. Black and Caspian). The examination of geologic and tectonic features of these areas is crucial for the understanding of the mechanisms of mud volcanic activity. In the abyssal parts of inland seas, mud volcanoes have been found in the Caspian Sea and in the Black Sea where the sedimentary cover is typically thick (10-20 $\mathrm{km}$ ) for these regions. Sediments are mostly terrigenous and were deposited during Tertiary and recent times under high subsidence and accumulation rates. Shale diapirs and faults deform many sedimentary sequences.

On the continental slopes of passive margins, submarine mud volcanoes have been found in the Norwegian Sea, offshore Nigeria and in the Gulf of Mexico. In the first two cases, mud volcanic activity is confined to submarine fans (the Bear Island Trough mouth fan and the Niger Delta are notable examples), composed of Tertiary terrigenous sediments deposited at a high accumulation rate. In the Niger Delta there are many diapirs and faults [156]. The continental slope of the Gulf of Mexico is an extremely complex deep-water region characterized by a combination of rapid sediment influx, faulting, and diapiric (salt and shale) tectonism [157].

At active margins, submarine mud volcanoes have been reliably identified in the Mediterranean Sea and offshore Barbados, both characterized by different geologic and tectonic settings. In the Mediterranean Sea, mud volcanoes have been found only within the limits of the accretionary prism, characterized by a complex fabric composed of many thrusts [28]. Offshore Barbados mud volcanoes are located within the limits of the accretionary prism as 
well as in front of the prism where the thickness of sedimentary cover is only $2.3 \mathrm{~km}$ [158]. The majority of reported evidence of submarine mud volcanoes presents at active margins.

The association of gas hydrates with submarine mud volcanoes was first noted by Reference [145] and has since observed in the Caspian [42], Black [27,146-148], Mediterranean [57,148], Norwegian seas [48,58], offshore Barbados [159], offshore Nigeria [160] and in the Gulf of Mexico [161,162].

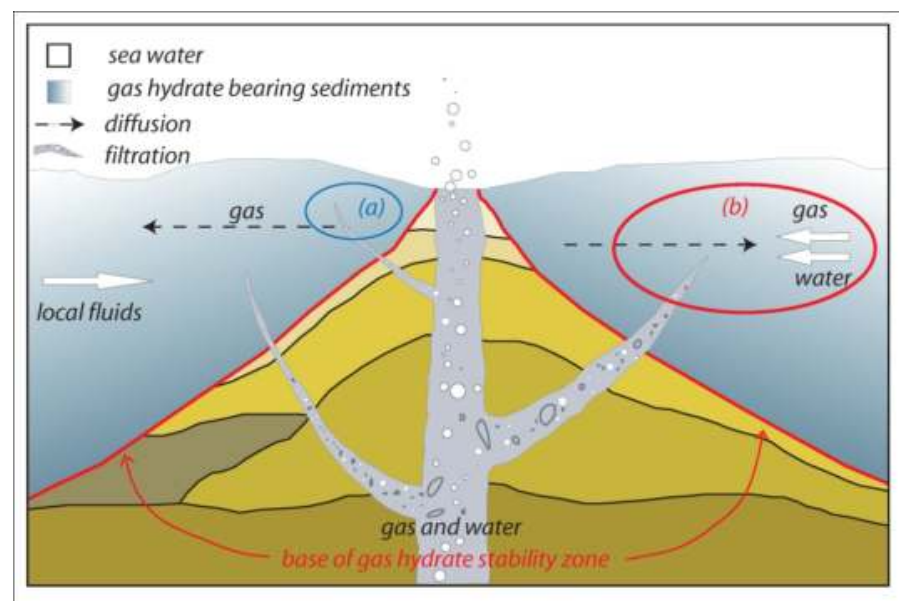

Figure 8. Cartoon showing the proposed model of the formation of gas hydrates within a mud volcano: (a) hydrothermal process dominates around the central part of the mud volcano; (b) metasomatic process dominates at the peripherical part of the mud volcano. Modified after [12].

There are many common features of gas hydrates associated with mud volcanoes. Gas hydrate content in sediments varies from $1-2 \%$ to $35 \%$ by volume and changes through a mud volcano area as well as through depth. Methane is the major gas component of gas hydrates and can be thermogenic, biogenic or mixed in origin. Reference [12] proposed a model for the formation of gas hydrates within a mud volcano: (a) hydrothermal process dominates around the central part of the mud volcano; (b) metasomatic process dominates at the peripherical part of the mud volcano (Figure 8). This generalized model is based mainly on data from the Haakon Mosby mud volcano in the Norwegian Sea, which is the most famous mud volcano characterized by a concentric-zonal distribution of gas hydrates $[58,163]$. Gas hydrate accumulation is controlled by the ascending flow of warm fluids. The water from the mud volcanic fluid as well as from the surrounding recent sediments is involved in the formation of gas hydrates. So, gas hydrates can occur within the edifice of a mud volcano (crater and hummocky periphery) as well as outside in the host marine sediments. However, the processes that are responsible for the formation of gas hydrates differ from point to point. Note that in Figure 8 there are no gas hydrates in the central part of the model mud volcano (usually in the central part of a crater where mud and fluid flow out) because of the high temperature. Around the central part of the mud volcano, gas hydrates form from the 
fluids that have risen from the deep subsurface. This fluid is warmer than the surrounding sediments (by up to $15-20^{\circ} \mathrm{C}$ at the sub-bottom depth of $1 \mathrm{~m}$ ) and contains gas in solution and perhaps as a free phase. Gas hydrates crystallize from this warm fluid when it becomes cold and the solubility of gas decreases [164]. Both water and gas participating in the formation of gas hydrates have come from the deep, external fluid that filters through mud volcanic sediments. This process is analogous to the conventional low-temperature hydrothermal process of mineral formation [165].

At the peripheral part of the mud volcano, gas hydrates form from the gas that emanates from the central part of the mud volcano, and is transported in solution by diffusion. On the other hand, the water participating in the formation of gas hydrates is contained in the host sediments (local water). In addition, some local biochemical gas may be captured in gas hydrates. Thus, in this case the local water is partly replaced by gas hydrates due to the supply of gas from an external source (mud volcanic fluid). This process of gas hydrate formation is analogous to the conventional metasomatic process of mineral formation [165]. At any point between the central and peripheral parts of the mud volcano, mixing of hydrothermal and metasomatic processes is possible. The source of water (mud volcanic or local) determines which of these two processes is dominant.

The close proximity of mud volcanoes to zones where BSRs crop out on the seafloor deserves particular attention. Seismic records strongly suggest that much of the gas in mud volcanoes originates from levels deeper than that of the gas hydrates and faulting could be responsible for this unique situation. It has been argued that, in the case that a concentric zonal distribution of hydrate is present, the gas hydrates have probably been formed by gas emanating from the central part of the mud volcano, and transported into solution by diffusion [12]. For example, a strong BSR and the presence of mud volcanoes have recently been detected by seismic data along the southwest African margin, which is a passive margin [166]. This region, located in the distal part of the Orange River delta, is also characterized by overpressure which results in active fluid expulsion, as shown by the existence of mud volcanoes, pockmarks, and possibly cold-water corals thriving on methane gas seeps [167].

\section{An example: The Antarctic Peninsula}

The global climate change is particularly amplified in transition zones, such as the peri-Antarctic regions. For this reason, the gas hydrate reservoir present offshore Antarctic Peninsula was studied in the last 20 years acquiring a quite extensive geophysical dataset. The presence of a diffused and discontinuous BSR was discovered during the Italian Antarctic cruises of 1989-1990 [i.e., 30] and 1996-1997 [122], onboard the R/V OGS Explora. Seismic data showed the existence of a potential gas hydrate reservoir $[32,168]$ along the South Shetland margin. Along this margin, the extent of the BSR was mapped based on about 1,000 km of seismic lines [e.g.,168 and references therein]. Ocean bottom seismometers (OBSs) deployed during the 1996-1997 cruise provided energy arrivals from the BSR and the refraction and the converted waves from the base of the free-gas zone, the so-called base of the free gas re- 
flector or BGR [122]. During the austral summer 2003-2004, additional data were acquired in the same area: multibeam bathymetry, seismic profiles, chirp, and sediment gravity cores [31]. Figure 9 summarizes the position of the three acquisition legs.
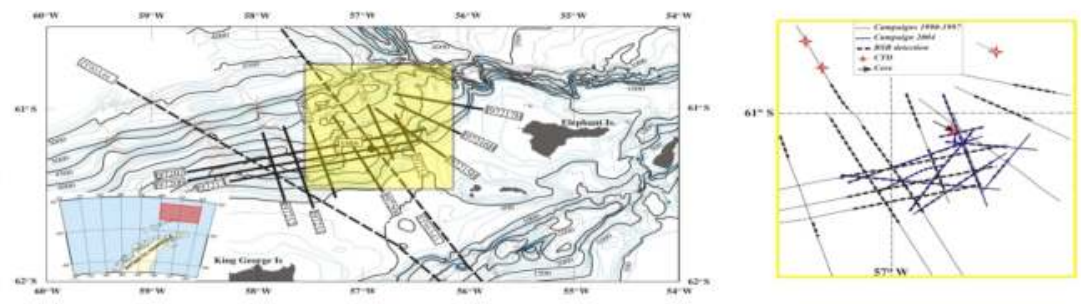

Figure 9. Left: Multibeam bathymetry map after [169], showing the locations of the seismic lines acquired in 1990 (dashed lines) and 1997 (continuous lines). The dot indicates the location of the OBS data acquired in 1997. The yellow box presents the 2004 study area. Right: 2004 study area. Continuous blue lines: locations of the airgun seismic lines. Dotted black lines: location of seismic lines of 1990 and 1997 legs. Thick dashed segments indicate the presence of particularly well developed BSRs. Also annotated are the CTD measurements (red stars), and the two coring sites (grey and black arrows cores GC01 and GC02 respectively). Modified after [31].

As already explained, seismic velocity obtained from advanced seismic analysis can be translated in terms of concentrations of gas hydrate and free gas. This procedure has been applied in the Antarctic Peninsula, where seismic velocities obtained from advanced analysis of multichannel seismic data were analyzed to determine gas hydrate and free-gas distributions and to estimate the methane volumetric fraction trapped in the sediments [170]. The elastic properties of the layers across the BSR were modeled applying the approximation of the Biot equations for seismic frequency in order to quantify the concentrations of gas hydrate and free gas in the pore space [128]. This theory considers two solid phases - grains and hydrates - and two fluid phases - water and free gas - including an explicit dependence on differential pressure and depth, and the effects of cementation by hydration on the shear modulus of the sediment matrix. So, the seismic velocities of the 2D seismic lines were translated in terms of concentrations of gas hydrate and free gas in the pore space, obtaining 2D models. The jointly interpolation of the 2D models allowed obtaining a 3D model of gas hydrate concentration from the seafloor to the BSR. The total volume of hydrate, estimated in the area $\left(600 \mathrm{~km}^{2}\right)$ where the interpolation is reliable, is $16 \times 10^{9} \mathrm{~m}^{3}$. The gas hydrate concentration is affected by errors that could be equal to about $\pm 25 \%$, as deduced from sensitivity tests $[31,171]$ and from error analysis related to the interpolation procedure. The estimated amount of gas hydrate can vary in a range of $12 \times 10^{9}-20 \times 10^{9} \mathrm{~m}^{3}$. Moreover, considering that $1 \mathrm{~m}^{3}$ of gas hydrate corresponds to $140 \mathrm{~m}^{3}$ of free gas in standard conditions, the total free gas trapped in this reservoir ranges between $1.68 \times 10^{12}$ and $2.8 \times 10^{12} \mathrm{~m}^{3}$. This estimation does not take into account the free gas contained within pore space below the hydrate layer, so this values could be underestimated. 


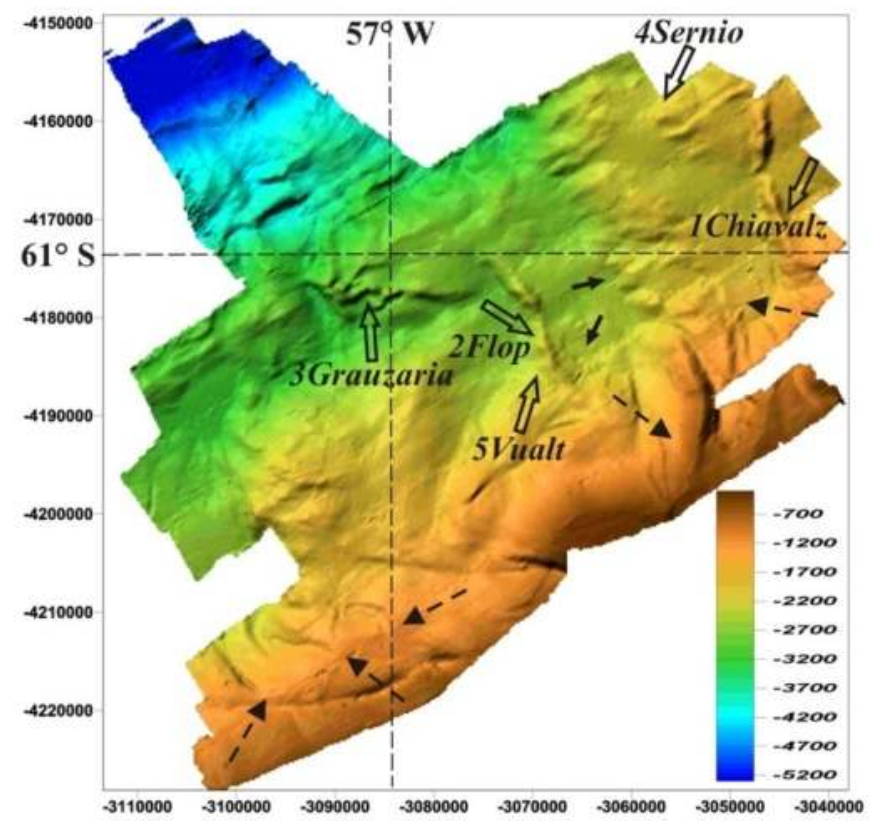

Figure 10. Multibeam bathymetry map of the study area, showing evidence of mud volcanoes (open arrows), collapse troughs (closed arrows) and slides (dashed arrows). The numbers indicate the four mud volcano ridges described in the text and in Table 1. Modified after [31].

Reference [31] reported the main results obtained by the analysis of bathymetric data, CHIRP data and gravity core analysis. In particular, the bathymetric map provided the evidences of mud volcanoes, collapse troughs and slides (Figure 10). It is well known [i.e., 172] that these features are generally associated to the presence of gas hydrate, as already explained. Reference [31] have recognized five main mud volcano ridges, named Chiavalz, Flop, Grauzaria, Sernio and Vualt (see location map in Figure 10). Table 1 reports the main characteristics of the mud volcanoes (Figures 11-15). The Vualt mud volcano is the highest detected in our study area; its top is at 2,216 m below sea level, with an elevation of about $255 \mathrm{~m}$ above the seafloor and an extension of $9.4 \mathrm{~km}^{2}$ (Figure 10, label 5; Figure 11). On the flank, a gravity core (GC02) was recovered. The Flop mud volcano has its top at 2,363 m below sea level and a relief of about $115 \mathrm{~m}$. Its extension is $7.5 \mathrm{~km}^{2}$ (Figure 10, label 2; Figure 12). The Grauzaria ridge, oriented W-E and located at around 61 S-57 W (Figure 10; label 3; Figure 13), can be considered an alignment with several culminations and a total extension of $45.9 \mathrm{~km}^{2}$. The highest culmination is at 2,594 m below sea level and exhibits a relief of about $185 \mathrm{~m}$ above the seafloor. The Sernio mud volcano ridge is located in the proximity of core GC01 and is oriented SW-NE (Figure 10, label 4; Figure 14). Its top is at 1,990 m below sea level with an elevation of about $185 \mathrm{~m}$. It presents several culminations for a total exten- 
sion of $23.9 \mathrm{~km}^{2}$. Finally, the Chiavalz mud volcano ridge is located in the northeast of our survey area (Figure 10; label 1; Figure 15) and is oriented S-NE. It has its top at 1,615 m below sea level, a maximum elevation of about $210 \mathrm{~m}$, and an extension of $14.5 \mathrm{~km}^{2}$.

\begin{tabular}{lccccc}
\hline Mud Volcano & Lat. (WGS84) & Lon. (WGS84) & $\begin{array}{c}\text { Meter below } \\
\text { seafloor of the top }\end{array}$ & $\begin{array}{l}\text { Elevation (m) } \\
\left.\text { Extension (km }{ }^{2}\right)\end{array}$ \\
\hline 1 Chiavalz & $605229.31 \mathrm{~S}$ & $561846.88 \mathrm{~W}$ & 1615 & 210 & 14.5 \\
\hline 2 Flop & $610140.52 \mathrm{~S}$ & $564511.88 \mathrm{~W}$ & 2363 & 115 & 7.5 \\
\hline 3 Grauzaria & $610131.44 \mathrm{~S}$ & $565636.64 \mathrm{~W}$ & 2594 & 185 & 45.9 \\
\hline 4 Sernio & $605154.73 \mathrm{~S}$ & $562819.10 \mathrm{~W}$ & 1990 & 185 & 23.9 \\
\hline 5 Vualt & $610430.63 \mathrm{~S}$ & $564302.71 \mathrm{~W}$ & 2216 & 255 & 9.4 \\
\hline
\end{tabular}

Table 1. Details of the mud volcanoes offshore Antarctic Peninsula: latitude and longitude of the midpoint, water depth at the top, elevation with respect to the bathymetry and extension. Grauzaria is a group of several mud volcanoes.

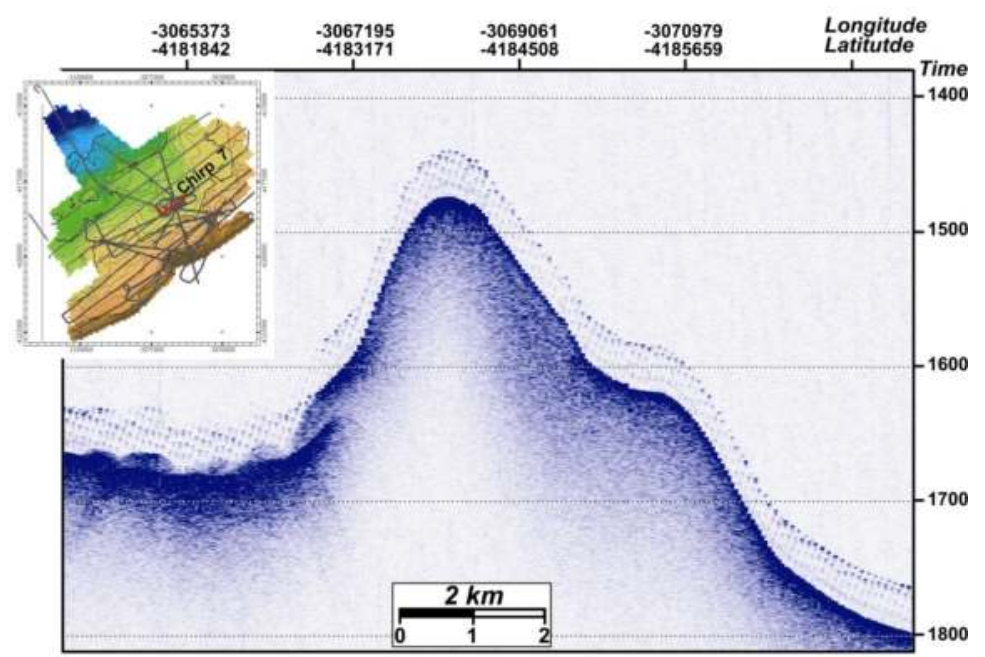

Figure 11. Comparison between chirp (a) and airgun (b) data across the Vualt mud volcano, in which the BSR is evident. The arrow indicates the location of core GC02. CHIRP image of the Vualt. Insert: Bathymetric map after BSR project. The red line indicates the CHIRP location. After [31].

Fluid analyses performed on the two gravity cores [31] revealed the presence of several hydrocarbon gases, i.e. methane, ethane, propane, butane, pentane and hexane, and traces of aromatic hydrocarbons of $>\mathrm{C} 12$ carbon chain length, suggesting a thermogenic origin of the gas. The major difference in gas contents between the two cores is that methane and propane are totally absent in core GC02. On the contrary, pentane is present at all analyzed 
depths in both cores, with quite similar contents. Below the upper $1 \mathrm{~m}$ of sediment in core GC02, the interstitial gases are essentially composed of pentane. The average total gas content amounts to 150.54 and $49.30 \mu \mathrm{g} / \mathrm{kg}$ for the two cores, respectively. The gas content measured in core GC01 is therefore about three times higher than that measured in core GC02. Downcore profiles for specific gases showed that core GC01 has a quite uniform gas type and content along the whole core; on the contrary, core GC02 has variable gas content. Even if both cores are located in the proximity of mud volcanoes, Reference [31] suggested that the sediment permeability of core GC01 is lower than that of core GC02, in which the fluids can easily escape and produce a collapse trough (see closed arrows in Figure 10). Moreover, the sediment stiffness in core GC01 is higher than that of core GC02, as suggested also by the different core length (1.07 and $2.98 \mathrm{~m}$ respectively); this is in agreement with the hypothesis of different permeability values between the two cores.

In conclusion, interpretation of the data acquired on the South Shetland margin confirmed the crucial role of tectonics controlling the extent of the hydrate reservoir, and active venting of fluids and mud through faults bordering and crossing the gas hydrate field. Mud volcanoes and fluid expulsion events are likely located in close association with faults, through which they are connected to the reservoir located beneath the BSR. Their activity is probably episodic [31]. Moreover, the different sediment stiffness at the two coring sites can be related to the temporal frequency of expulsion events, where the hardness of the mud volcano flanks is directly proportional to the interval between expulsion events, as suggested by [173]. Finally, the hydrocarbons trapped in our sediment cores possibly indicate the existence of deeper reserves.

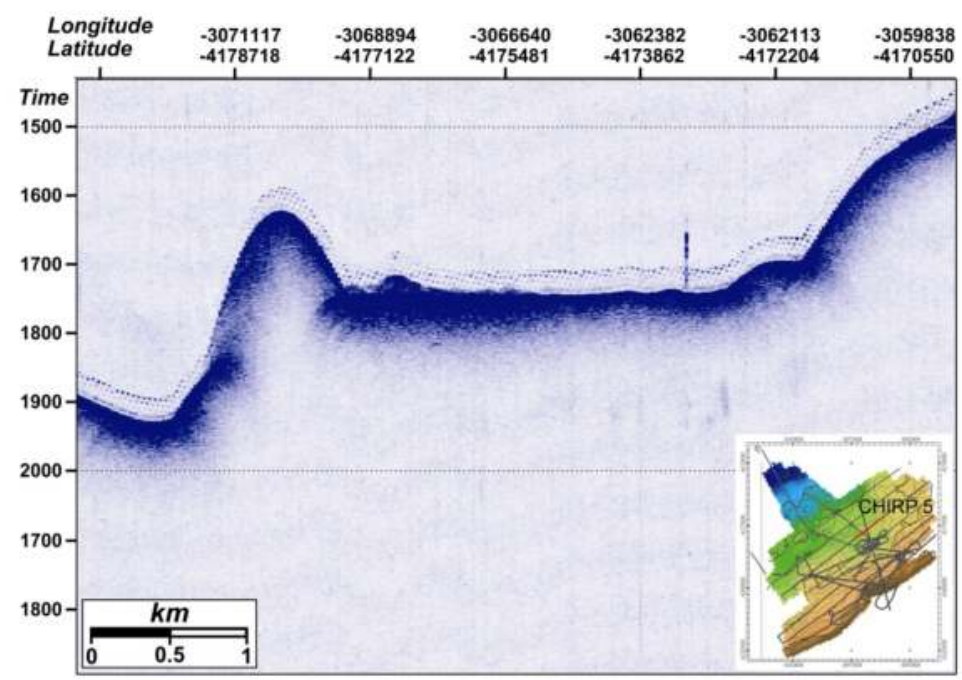

Figure 12. CHIRP image of the Flop. Insert: Bathymetric map after BSR project. The red line indicates the CHIRP location. 


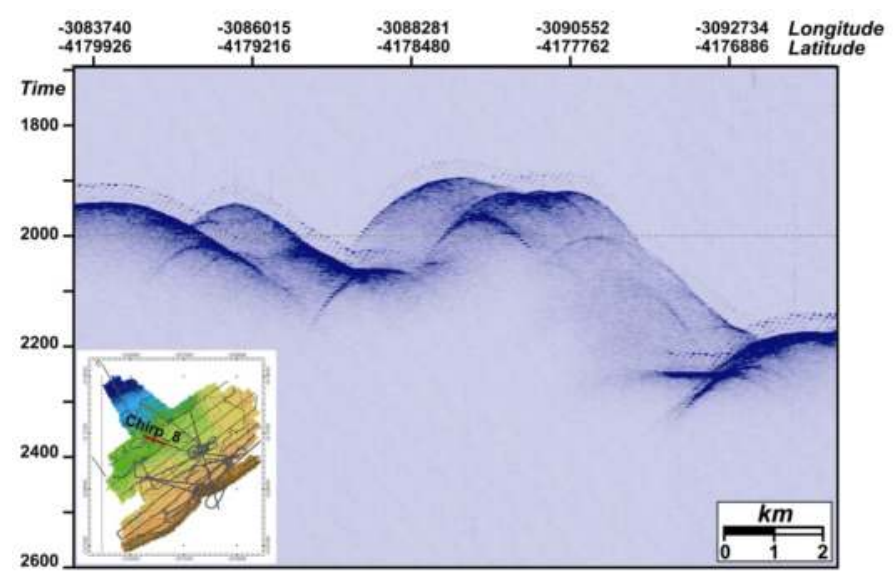

Figure 13. CHIRP images of the Grauzaria group. Insert: Bathymetric map after BSR project. The red line indicates the CHIRP location.

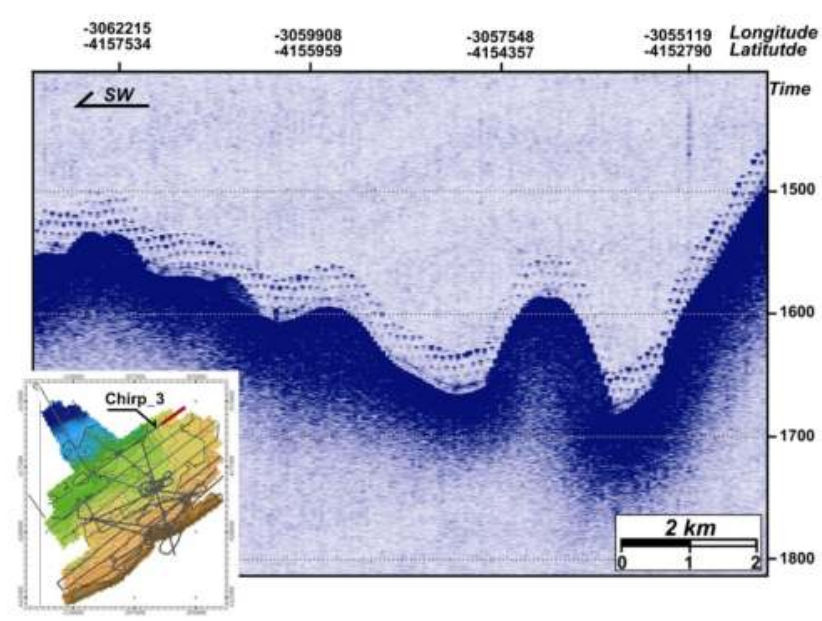

Figure 14. CHIRP images of the Sernio mud volcano. Insert: Bathymetric map after BSR project. The red line indicates the CHIRP location.

\section{Conclusions}

Knowledge of natural occurring gas hydrate is increasing rapidly in the last years; however commercialization of gas hydrate remains unproven. Great uncertainty of the global gas hydrate resource and imitated estimates of hydrate system retard economic analysis of hydrate 
recovery [174]. In this context, the gas hydrate associated to mud volcanoes is a very interesting topic because this system contains high gas hydrate concentration in a very small area. In addition, gas hydrate accumulations related to fluid discharges sites (including mud volcanoes) occur at very shallow depths or on the seafloor and show the maximum hydrate content in their upper parts. These features may consider as natural reactors, in which part of the migrating gas from the surrounding areas is stabilized in gas hydrates. Gas resources in such accumulations are therefore renewable and could become important gas hydrate formations to be exploited [11].

Moreover, the wide and extensive literature about hydrate, mud volcanism and their interaction suggests that this topic is timely because gas hydrates may play an important role in the global carbon cycle and global climate dynamics through emissions of methane and in affecting stability of geological features, including mud volcanoes. The role of gas hydrates in above-mentioned processes cannot be assessed accurately without a better understanding of the hydrate reservoir and their interactions with geological features and meaningful estimates of the amount of methane it contains. In conclusion, lack of knowledge hampers the evaluation of the resource potential of gas hydrates and the hazards related to gas hydrates, requiring efforts to improved knowledge about gas hydrate and their interaction with mud volcanoes.

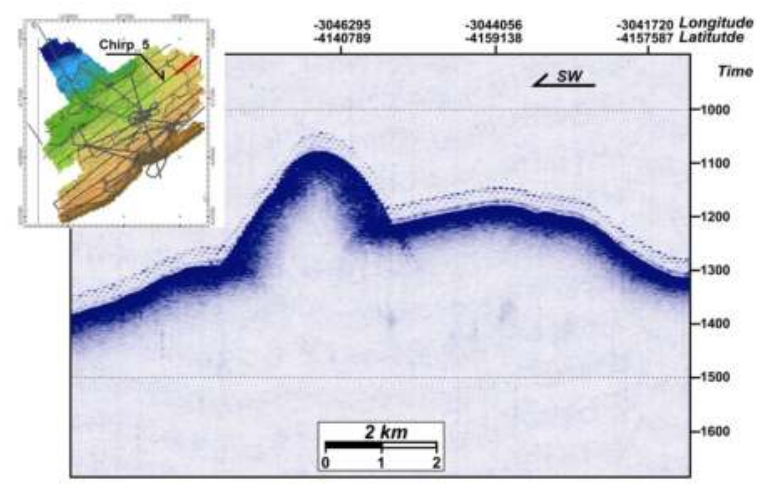

Figure 15. CHIRP images of the Chiavalz mud volcano. Insert: Bathymetric map after BSR project. The red line indicates the CHIRP location.

\section{Acknowledgements}

We wish to thank Manuela Sedmach for graphic support. This work is partially supported by Programma Nazionale di Ricerche in Antartide, project CLISM. 


\section{Author details}

Umberta Tinivella* and Michela Giustiniani

*Address all correspondence to: utinivella@inogs.it

OGS - National Institute of Oceanography and Experimental Geophysics, Borgo Grotta Gigante 42C, 34010, Trieste, Italy

\section{References}

[1] Canon-Tapia, E., \& Szakacs, A. (2010). What is a volcano? Boulder, Colo.: Geological Society of America. 140.

[2] van Loon, A. J. (2010). Sedimentary volcanoes: Overview and implications for the definition of a volcano on Earth. Canon-Tapia E, Szakacs A, Editors. What is a volcano?. Boulder, Colo.: Geological Society of America, 31-41.

[3] Kopf, A. J. (2011). Significance of mud volcanism. Reviews of Geophysics, 40(2).

[4] Hensen, C., Nuzzo, M., Hornibrook, E., Pinheiro, L.M., Bock, B., Magalhães, V. H., \& Brückmann, W. (2007). Sources of mud volcano fluids in the Gulf of Cadiz- indications for hydrothermal imprint. Geochimica et Cosmochimica Acta, 71, 1232-1248.

[5] Etiope, G., \& Klusman, R. W. (2002). Geologic emissions of methane to the atmosphere. Chemosphere, 49, 777-789.

[6] Judd, A. G., Hovland, M., Dimitrov, L. I., García, Gil. S., \& Jukes, V. (2002). The geological methane budget at Continental Margins and its influence on climate change. Geofluids, 2, 109-126.

[7] Dimitrov, L. I. (2003). Mud volcanoes-a significant source of atmospheric methane. Geo-Mar Lett, 23, 155-161, doi: s00367-003-0140-3.

[8] Milkov, A. V., Sassen, R., Apanasovich, T. V., \& Dadashev, F. G. (2003). Global gas flux from mud volcanoes: a significant source of fossil methane in the atmosphere and the ocean. Geophysical Research Letters, 30, doi:10.1029/2002GL016358.

[9] Etiope, G., \& Milkov, A. V. (2004). A new estimate of global methane flux from onshore and shallow submarine mud volcanoes to the atmosphere. Environmental Geolo$g y, 46,997-1002$.

[10] Judd, A. (2005). Gas emissions from mud volcanoes. Significance to Global Climate Change. Martinelli G., Panahi B., (ed.) Mud Volcanoes, Geodynamics and Seismicity, 51, chapter 4, 147-157. 
[11] Mazurenko, L. L., \& Soloviev, V. A. (2003). Worldwide distribution of deep-water fluid venting and potential occurrences of gas hydrate accumulations. Geo-Marine Letters, 23, 162-176.

[12] Milkov, A. V. (2000). Worldwide distribution of submarine mud volcanoes and associated gas hydrates. Marine Geology, 167, 29-42.

[13] Dimitrov, L. I. (2002). Mud volcanoes-the most important pathway for degassing deeply buried sediments. Earth-Science Reviews, 59, 49-76.

[14] Hovland, M., Hill, A., \& Stokes, D. (1997). The structure and geomorphology of the Dashgil mud volcano, Azerbaijan. Geomorphology, 21, 1-15.

[15] Kopf, A., Klaeschen, D., \& Mascle, J. (2001). Extreme efficiency of mud volcanism in dewatering accretionary prisms. Earth and Planetary Science Letters, 189, 295-313.

[16] Delisle, G., von, Rad. U., Andruleit, H., von, Daniels. C. H., Tabrez, A. R., \& Inam, A. (2002). Active mud volcanoes on- and offshore eastern Makran, Pakistan. International Journal of Earth Sciences. 91, 93-110.

[17] Etiope, G., Caracausi, A., Favara, R., Italiano, F., \& Baciu, C. (2002). Methane emissions from the mud volcanoes of Sicily (Italy). Geophysical Research Letters, 29(8), 56-1-56-4.

[18] Deville, E., Battani, A., Griboulard, R., Guerlais, S., Herbin, J. P., Houzay, J. P., Muller, C., \& Prinzhofer, A. (2003). The origin and processes of mud volcanism: new insights from Trinidad. Van Rensbergen P, Hillis RR, Maltman AJ, Morley CK. (ed.) Subsurface Sediment Mobilization. Geol. Soc. London, Spec. Publs., 216, 475-490.

[19] Yassir, N. (2003). The role of shear stress in mobilizing deep-seated mud volcanoes: geological and geomechanical evidence from Trinidad and Taiwan. Van Rensbergen $P$, Hillis RR, Maltman AJ, Morley CK. (ed.) Subsurface Sediment Mobilization. Geol. Soc. London, Spec. Publs., 216, 461-474.

[20] Shakirov, R., Obzhirov, A., Suess, E., Salyuk, A., \& Biebow, N. (2004). Mud volcanoes and gas vents in the Okhotsk Sea area. Geo-Marine Letters, 24, 140-149.

[21] Stewart, S. A., \& Davies, R. J. (2006). Structure and emplacement of mud volcano systems in the South Caspian Basin. AAPG Bulletin, 90(5), 771-786.

[22] Barber, A. J., Tjokrosapoetro, S., \& Charlton, T. R. (1986). Mud volcanoes, shale diapirs, wrench faults and me'langes in accretionary complexes, eastern Indonesia. AAPG Bull, 70, 1729-1741.

[23] Orange, D. L. (1990). Criteria helpful in recognizing shear-zone and diapiric melenges, examples from the Hoh accretionary complex, Olympic Peninsula, Washington. Geol. Soc. Am. Bull., 102, 935-951.

[24] Brown, K. M., \& Orange, D. L. (1993). Structural aspects of diapiric melange emplacement: The Duck Creek diaper. Journal of Structural Geology, 13, 831-847. 
[25] Treves, B. (1985). Mud volcanoes and shale diapirs, their implications in accretionary processes. A review. Acta Naturalia de l'Ateneo Parmense, 21, 31-37.

[26] Guliyiev, I. S., \& Feizullayev, A. A. (1997). All About Mud Volcanoes. Azerbaijan, Baku: Publ. House, Nafta Press.

[27] Ivanov, M. K., Limonov, A. F., \& Woodside, J. M. (1998). Extensive deep fluid flux through the sea floor on the Crimean continental margin (Black Sea). Henriet JP, Mienert J. (ed.) Gas hydrates: relevance to world margin stability and climate change. Geol. Soc. London, Spec. Publs., 137, 195-213.

[28] Limonov, A. F., Woodside, J. M., Cita, M. B., \& Ivanov, M. K. (1998). The Mediterranean Ridge and related mud diapirism: a background. Mar. Geol., 132, 7-19.

[29] Kvenvolden, K. A., \& Lorenson, T. D. (2000). The global occurrence of natural gas hydrate. Paull C.K., Dillon W. P. (ed.) Natural Gas Hydrates: Occurrence, Distribution, and Dynamics, AGU Monograph, 55.

[30] Tinivella, U., Lodolo, E., Camerlenghi, A., \& Boehm, G. (1998). Seismic tomography study of a bottom simulating reflector off the South Shetland Islands (Antarctica). Henriet J-P, Mienert J, (ed.) Gas hydrate: relevance to world margin stability and climate change. Geol. Soc. London, Spec. Publs., 147, 141-151.

[31] Tinivella, U., Accaino, F., \& Della Vedova, B. (2007). Gas hydrates and active mud volcanism on the South Shetland continental margin, Antarctic Peninsula. Geo-Mar Lett, doi s00367-007-0093-z.

[32] Tinivella, U., Loreto, M. F., \& Accaino, F. (2009). Regional versus detailed velocity analysis to quantify hydrate and free gas in marine sediments: the South Shetland margin target study. Long D., Lovell M.A., Ress J.G., Rochelle CA. (ed.) Sediment-Hosted Gas Hydrates: New Insights on Natural and Synthetic Systems. Geol. Soc. London, Spec. Publs. , 319, 103-119.

[33] Rakhmanov, R. R. (1987). Mud volcanoes and their importance in forecasting of subsurface petroleum potential. Nedra (in Russian).

[34] Lancelot, Y., \& Embley, R. W. (1977). Piercement structures in deep oceans. Bull. Amer. Assoc. Pet. Geol., 61, 1991-2000.

[35] Graue, K. (2000). Mud volcanoes in deep water Nigeria. Marine and Petroleum Geology. $17,959-974$.

[36] Huguen, C., Mascle, J., Chaumillon, E., Kopf, A., Woodside, J., \& Zitter, T. (2004). Structural setting and tectonic control of mud volcanoes from the Central Mediterranean Ridge (Eastern Mediterranean). Marine Geology, 209, 245-263.

[37] Huseynov, D. A., \& Guliyev, I. S. (2004). Mud volcanic natural phenomena in the South Caspian Basin: geology, fluid dynamics and environmental impact. Environmental Geology, 46, 1012-1023. 
[38] Martinelli, G. (1998). Mudvolcanoes of Italy: proceedings of V Int. Conference on "Gas in Marine Sediments", 40-42.

[39] Arhangelski, A. (1932). Some words about genesis of mud volcanoes on the Apsheron peninsula and Kerch-Taman area. Bull. MOIP, Ser. Geol., 3: 269-285 (in Russian).

[40] Gubkin, I., \& Feodorov, S. (1932). Mud volcanoes of the USSR in connection with oil and gas prospects. Proceedings of 27th Int. Geol. Congr. Moscow -(in Russian) , 4, 33-67.

[41] Jakubov, A. A., Ali-Zade, A. A., \& Zeinalov, M.M. (1971). Mud volcanoes of the Azerbaijan, SSR-Atlas. Baku: Publishing house of the Academy Sciences of the Azerbaijan SSR, 245.

[42] Ginsburg, G. D., \& Soloviev, V. A. (1994). Mud volcano gas hydrates in the Caspian Sea. Bull. Geol. Soc. Denm, 41, 95-100.

[43] Higgins, G. E., \& Saunders, J. B. (1973). Mud volcanoes-their nature and origin: contribution to the geology and paleobiology of the Carribbean and adjacent areas. Verh. Naturforsch. Geschel. Basel, 84, 101-152.

[44] Williams, P., Pigram, C., \& Dow, D. (1984). Melange production and the importance of shale diapirism in accretionary terrains. Nature, 309, 145-146.

[45] Mazurenko, L. L., Soloviev, V. A., Belenkaya, I., Ivanov, M. K., \& Pinheiro, L. M. (2002). Mud volcano gas hydrates in the Gulf of Cadiz. Terra Nova, 14, 321-329.

[46] Müller, C., Theilen, F., \& Milkereit, B. (2001). Large gasprospective areas indicated by bright spots. World Oil, 222(1).

[47] Perez-Belzuz, F., Alonso, B., \& Ercilla, G. (1997). History of mud diapirism and triggering mechanisms in the Western Alboran Sea. Tectonophysics, 282, 399-423.

[48] Vogt, P. R., Cherkashev, G., Ginsburg, G., Ivanov, G., Milkov, A., Crane, K., Lein, A., Sunvor, E., Pimenov, N., \& Egorov, A. (1997). Haakon Mosby mud volcano provides unusual example of venting. EOS Trans Am Geophys Union, 78(48), 556-557.

[49] Paine, W. R. (1968). Recent peat diapirs in the Netherlands: A comparison with Gulf Coast salt structures. In: Braunstein G.,. O'Brien G.D. (ed.) Diapirism and Diapirs., AAPG Mem., 8, 271-274.

[50] Neurauter, T. W., \& Roberts, H. H. (1994). Three generations of mudvolcanoes on the Louisiana continental slope. Geo-Mar. Lett., 14, 120-125.

[51] Planke, S., Svensen, H., Hovland, M., Banks, D. A., \& Jamtveit, B. (2003). Mud and fluid migration in active mud volcanoes in Azerbaijan. Geo-Marine Letters, 23, 258-268.

[52] Etiope, G. (2005). Methane emission from mud volcanoes. Martinelli G, Panahi B (ed.) Mud Volcanoes, Geodynamics and Seismicity. Springer. 
[53] Sassen, R., Losh, S. L., Cathles, L., Roberts, H. H., Whelan, J. K., Milkov, A. V., Sweet, S. T., \& De Freitas, D. A. (2001). Massive vein filling gas hydrate: relation to ongoing migration from the deep subsurface in the Gulf of Mexico. Mar. Pet. Geol., 18(5), 551-560.

[54] Limonov, A. F., van Weering, T. C. E., Kenyon, N. H., Ivanov, M. K., \& Meisner, L. B. (1997). Seabed morphology and gas venting in the Black Sea mudvolcano area: observations with the MAK-1 deep-tow sidescan sonar and bottom profiler. Mar. Geol., $137,121-136$.

[55] Foucher, J. P., \& De Lange, G. (1999). Submersible observations of cold seeps on eastern Mediterranean mud volcanoes. Proceedings of J. Conf. Abstr. EUG 10, Strasbourg, France, B13 4(1).

[56] Reed, D. L., Silver, E. A., Tagudin, E., Shipley, H., \& Volijk, P. (1990). Relations between mud volcanoes, thrust deformation, slope sedimentation, and gas hydrate, offshore north Panama. Mar. Pet. Geol., 7, 44-54.

[57] Woodside, J. M., Ivanov, M. K., \& Limonov, A. F. (1998). Shipboard Scientists of the Anaxiprobe Expeditions. Shallow gas and gas hydrates in the Anaximander Mountains regions, eastern Mediterranean Sea. Henriet JP, Mienert J. (ed.) Gas Hydrates: Relevance to World Margin Stability and Climate Change. Geol. Soc. London, Spec. Publ. , 137, 177-193.

[58] Ginsburg, G. D., Milkov, A. V., Soloviev, V. A., Egorov, A. V., Cherkashev, G. A., Crane, K., Lorenson, T. D., \& Khutorskoy, . (1999). Gas hydrate accumulation at the Haakon Mosby mud volcano. Geo-Mar. Lett., 19, 57-67.

[59] Dimitrov, L. I., \& Woodside, J. (2003). Deep sea pockmark environments in the eastern Mediterranean. Marine Geology, 195, 263-276.

[60] Evans, R. J., Davies, R. J., \& Stewart, S. A. (2006). Internal structure and eruptive history of a kilometrescale mud volcano system, South Caspian Sea. Basin Research, 19, 153-163.

[61] Hedberg, H. D. (1974). Relation of methane generation to undercompacted shales, shale diapirs and mud volcanoes. Bull. Am. Assoc. Pet. Geol, 58, 661-673.

[62] Ali-Zade, A. A., Shnyukov, E. F., Grigoryants, B. V., Aliyev, A. A., \& Rakhmanov, R. R. (1984). Geotectonic conditions of mud volcano manifestation in the world and their role in prediction of gas and oil content in the earth's interior: proceedings of 27th International Geological Congress. 13, 377-393.

[63] Guliyiev, I. S. (1992). A review of mud volcanism. Translation of the report by: Azerbaijan Academy of Sciences Institute of Geology, 65.

[64] Manga, M., \& Brodsky, E. (2006). Seismic triggering of Eruptions in the Far Field: Volcanoes and Geysers. Annual Review of Earth and Planetary Science, 34, 263-291. 
[65] Svensen, H., Jamtveit, B., Planke, S., \& Chevallier, L. (2006). Structure and evolution of hydrothermal vent complexes in the Karoo Basin,South Africa. Journal of the Geological Society, 163, 671-682.

[66] Skogseid, J., Pedersen, T., Eldholm, O., \& Larsen, B. T. (2010). Tectonism and magmatism during NE Atlantic continental break-up: the Vøring Margin. Storey B C, Alabaster T, Pankhurst, $R$ J, Editors. Magmatism and the Causes of Continental Break-up. London, Geological Society , 68, 305-320.

[67] Svensen, H., Planke, S., Jamtveit, B., \& Pedersen, T. (2003). Seep carbonate formation controlled by hydrothermal vent complexes: a case study from the Vøring Basin, the Norwegian Sea. Geo-Marine Letters, 23, 351-358.

[68] Planke, S., Rassmussen, T., Rey, S. S., \& Myklebust, R. (2005). Seismic characteristics and distribution of volcanic intrusions and hydrothermal vent complexes in the Vøring and Møre basins. Dore A, Vining B, Editors. Petroleum Geology: North-West Europe and Global Perspectives. Proceedings of the 6th Geology Conference. London, 833-844.

[69] Bell, B., \& Butcher, H. (2002). On the emplacement of sill complexes: evidence from the Faroe-Shetland Basin. Jolley D W, Bell B R, Editors. The North Atlantic Igneous Province: Stratigraphy, Tectonic, Volcanic and Magmatic Processes. London Geological Society, Special Publications, 197, 307-329.

[70] Du, Toit. A. L. (2002). Geological Survey of Elliot and Xalanga, Tembuland. Annual Report of the Geological Commission Cape of Good Hope for 1903, 8, 169-205.

[71] Du, Toit. A. L. (1912). Geological Survey of Part of the Stormbergen. Annual Report of the Geological Commission Cape of Good Hope for 1911, 16, 112-136.

[72] Gevers, T. W. (1928). The volcanic vents of the Western Stormberg. Transactions of the Geological Society of South Africa, 31, 43-62.

[73] Stockley, G. M. (1947). Report on the Geology of Basutoland. Maseru, Authority of the Basutoland Government.

[74] Dingle, R. V., Siesser, W. G., \& Newton, A. R. (1983). Mesozoic and Tertiary Geology of Southern Africa. Rotterdam, Balkema.

[75] Jamtveit, B., Svensen, H., Podladchikov, Y. Y., \& Planke, S. (2004). Hydrothermal vent complexes associated with sill intrusions in sedimentary basins. Breitkreuz $C$, Petford N, Editors. Physical Geology of High-Level Magmatic Systems. London, Geological Society of London, Special Publications, 234, 233-241.

[76] Grapes, R. H., Reid, D. L., \& Mc Pherson, J. G. (1973). Shallow dolerite intrusions and phreatic eruption in the Allan Hills region, Antarctica. New Zealand. Journal of Geology and Geophysics, 17, 563-577.

[77] Hanson, R. E., \& Elliot, D. H. (1996). Rift-related Jurassic basaltic phreatomagmatic volcanism in the central Transantarctic Mountains: precursory stage to floodbasalt effusion. Bulletin of Volcanology, 58, 327-347. 
[78] White, J. D. L., \& Mc Clintock, M. K. (2001). Immense vent complex marks floodbasalt eruption in a wet, failed rift: Coombs Hills, Antarctica. Geology, 29, 935-938.

[79] Zolotukhin, V. V., \& Al'mukhamedov, A. I. (1988). Traps of the Siberian Platform. In: Macdougall JD, Editors. Continental Flood Basalts. Kluwer, Dordrecht, 273-310.

[80] Svensen, H., Planke, S., Malthe-Sørenssen, A., Jamtveit, B., Myklebust, R., Eidem, T., \& Rey, S. S. (2004). Release of methane from a volcanic basin as a mechanism for initial Eocene global warming. Nature, 429, 542-545.

[81] Wignall, P. B. (2001). Large igneous provinces and mass extinctions. Earth-Science Reviews, 53, 1-33.

[82] Courtillot, V. E., \& Renne, P. R. (2003). On the ages of flood basalt events. Comptes Rendus de l'Acade' mie des Sciences. Geoscience, 335, 113-140.

[83] Svensen, H., Bebout, G., Kronz, A., Li, L., Planke, S., Chevallier, L., \& Jamtveit, B. (2008). Nitrogen geochemistry as a tracer of fluid flow in a hydrothermal vent complex in the Karoo Basin, South Africa. Geochimica et Cosmochimica Acta, 72, 4929-4947.

[84] Mazzini, A., Nermoen, A., Krotkiewski, M., Podladchikov, Y., Planke, S., \& Svensen, H. (2009). Strike-slip faulting as a trigger mechanism for overpressure release through piercement structures. Implications for the Lusi mud volcano, Indonesia. Marine and Petroleum Geology, 26, 1751-1765.

[85] Mazzini, A., Svensen, H., Akhmanov, G. G., Aloisi, G., Planke, S., Malthe-Sorenssen, A., \& Istadi, B. (2007). Triggering and dynamic evolution of the LUSI mud volcano, Indonesia. Earth and Planetary Science Letters, 261(3-4), 375-388.

[86] Botha, B. V. J., \& Theron, J. C. (1966). New evidence for the early commencement of Stormberg volcanism. Tydskrif vir Natuurwetenskappe, 7, 469-473.

[87] Coetzee, C. B. (1966). An ancient volcanic vent on Boschplaat 369 in the Bloemfontein district, Orange Free State. Transactions of the Geological Society of South Africa, 69, 127-137.

[88] Taylor, N. C. (1970). The volcanic vents of the Stormberg series. BSc(Hons) project, Rhodes University, Grahamstown, South Africa.

[89] Seme, U. T. (1997). Diatreme deposits near Rossouw, north Eastern Cape:sedimentology-volcanology and mode of origin. BSc(Hons) project, Rhodes University, Grahamstown, South Africa.

[90] Woodford, A. C., Botha, J. F., Chevallier, L., et al. (2001). Hydrogeology of the main Karoo Basin: Current Knowledge and Research Needs. Water Research Commission Pretoria Report, 860.

[91] Navikov, L. A., \& Slobodskoy, R. M. (1979). Mechanism of formation of diatremes. International Geology Review, 21, 1131-1139. 
[92] Lorenz, V. (1985). Maars and diatremes of phreatomagmatic origin: a review. Transactions of the Geological Society of South Africa, 88, 459-470.

[93] Clement, C. R., \& Reid, A. M. The origin of kimberlite pipes: an interpretation based on a synthesis of geological features displayed.

[94] Webb, K. J., Smith, B. H., Paul, J. L., \& Hetman, C. M. (2004). Geology of the Victor Kimberlite, Attawapiskat, Northern Ontario, Canada: cross-cutting and nested craters. Lithos, 76, 29-50.

[95] Surtee southern African occurrences. (1989). Ross, J. et al. Editors. Kimberlites and Related Rocks. Geological Society of Australia, Special Publications, 14, 632-646.

[96] Mc Clintock, M. K., Houghton, B. F., Skilling, I. P., \& White, J. D. L. (2002). The volcaniclastic opening phase of Karoo flood basalt volcanism, Drakensberg Formation, South Africa. EOS Transactions of the American Geophysical Union, 83(47).

[97] White, J. D. L., \& Ross, P. S. (2011). Maar-diatreme volcanoes: A review. J Volcanol Geotherm Res, 201, 1-4, 1-29.

[98] Svensen, H., Planke, S., Chevallier, L., Malthe-Sorenssen, A., Corfu, F., \& Jamtveit, B. (2007). Hydrothermal venting of greenhouse gases triggering Early Jurassic global warming. Earth Planet. Sci. Lett., 256, 3-4, 554-566.

[99] Svensen, H., Planke, S., Polozov, A. G., Schmidbauer, N., Corfu, F., Podladchikov, Y. Y., \& Jamtveit, B. (2009). Siberian gas venting and the end-Permian environmental crisis. Earth Planet. Sci. Lett., 277(3-4), 490-500.

[100] Sloan, E. D., \& Koh, C. A. (2008). Clathrate Hydrates of Natural Gases, third ed. CRC Press, New York, Taylor and Francis Group, Publishers.

[101] Smelik, E. A., \& King, H. E. (1997). Crystal-growth studies of natural gas clathrate hydrates using a pressurized optical cell. American Mineralogist, 82, 88-98.

[102] Paull, C. K., \& Dillon, W. (2001). Natural gas hydrates: occurrence, distribution, and detection. AGU Monogr, 124, 1-315.

[103] Holder, G. D., Malone, R. D., \& Lawson, W. F. (1987). Effects of gas composition and geothermal properties on the thickness and depth of natural-gas-hydrate zone. Journal of Petroleum Technology, 1147-1152.

[104] Wright, J. F., Dallimore, S. R., Nixon, F. M., \& Duchesne, C. (2005). In situ stability of gas hydrate in reservoir sediments of the JAPEX/JNOC/GSC et al. Mallik 5L-38 gas hydrate production research well. Paper presented at Scientific Results from the Mallik 2002 Gas Hydrate Production Research Well Program, Mackenzie Delta, Geol. Surv. Canada, Northwest Territories, Canada.

[105] Dickens, G. R., \& Quinby-Hunt, M. S. (1994). Methane hydrate stability in seawater. Geophys. Res. Lett, 21, 2115-2118. 
[106] Subramanian, S., Kini, R.A., Dec, S.F., \& Sloan, E. D. (2000). Evidence of structure II hydrate formation from methane + ethane mixtures. Chemical Engineering Science, 55, 1981-1999.

[107] Lu, Z., \& Sultan, N. (2008). Empirical expressions for gas hydrate stability law, its volume fraction and mass-density at temperature $273.15 \mathrm{~K}$ to $290.15 \mathrm{~K}$. Geochemical Journal, 42, 163-175.

[108] Sultan, N., Cochonat, P., Foucher, J. P., \& Mienert, J. (2004). Effect of gas hydrates melting on seafloor slope instability. Marine Geology, 213, 379-401.

[109] Liu, X., \& Flemings, P. B. (2007). Dynamic multiphase flow model of hydrate formation in marine sediments. Journal of Geophysical Researcher, 112( B03101), doi: 10.1029/2005JB004227.

[110] Henriet, J. P., \& Mienert, J. (1998). Gas hydrates: relevance to world margin stability and climate change. Geol Soc Spec Publ , 137.

[111] Holder, G. D., \& Bishnoi, P. R. (2000). Gas Hydrates: Challenges for the Future. Ann. N.Y. Acad. Sci., 912.

[112] Kennett, J. P., Cannariato, K. G., Hendy, I. L., \& Behl, R. J. (2007). Carbon isotopic evidence for methane hydrate stability during Quaternary Interstadials. Science, 288, 128-133.

[113] Brooks, J. M., Cox, H. B., Bryant, W. R., Kennicutt, M. C., Mann, R. G., \& Mc Donald, T. J. (1986). Association of gas hydrates and oil seepage in the Gulf of Mexico. Organic Geochemistry, 10, 221-234.

[114] Severinghaus, J. P., Sowers, T., Brook, E. J., Alley, R. B., \& Bender, M. L. (1998). Timing of abrupt climate change at the end of the Younger Dryas interval from thermally fractionated gases in polar ice. Nature, 391, 141.

[115] Reagan, M. T., \& Moridis, G. J. (2007). Oceanic gas hydrate instability and dissociation under climate change scenarios. Geophysical Research Letters, 34(L22709), doi: 10.1029/2007GL031671.

[116] Kennett, J. P., Cannariato, K. G., Hendy, L. L., \& Behl, R. J. (2002). Methane Hydrates in Quaternary Climate Change: The Clathrate Gun Hypothesis. Spec. Publ., 54, AGU, Washington, D. C.

[117] Haq, B. U. (1998). Natural gas hydrates: searching for the long-term climatic and slope-stability records. Geological Society, London, Special Publications, 137, 303-318, doi:10.1144/GSL.SP.1998.137.01.24.

[118] Shipley, T. H., Houston, M. H., Buffler, R. T., et al. (1979). Seismic reflection evidence for widespread occurrence of possible gas-hydrate horizons on continental slopes and rises. AAPG Bull, 63, 2204-2213. 
[119] Shipley, T. H., \& Didyk, B. M. (1982). Occurrence of methane hydrates offshore southern Mexico. Watkins JS, Moore JC, et al., Editors. Init. Repts. DSDP, 66. Washington, U.S. Govt. Printing Office, 547-556.

[120] Minshull, T. A., Singh, S. C., Westbrook, G. K., et al. (1994). Seismic velocitystructure at a gas hydrate reflector,offshore western Colombia, from full waveform inversion. J. Geophys. Res., 99, 4715-4733.

[121] Sain, K., Minshull, T. A., Singh, S. C., \& Hobbs, R. W. (2000). Evidence for a thick free gas layer beneath the bottom simulating reflector in the Makran accretionary prism Marine Geology. 164, 37-51.

[122] Tinivella, U., \& Accaino, F. (2000). Compressional velocity structure and Poisson's ratio in marine sediments with gas hydrate and free gas by inversion of reflected and refracted seismic data (South Shetland Islands, Antarctica). Mar Geol, 164, 13-27.

[123] Dai, J,., Xu, H,., Snyder, F,., \& Dutta, N. (2004). Detection and estimation of gas hydrates using rock physics and seismic inversion: Examples from the northern deepwater Gulf of Mexico The Leading Edge. .

[124] Chand, S., \& Minshull, T. A. (2003). Seismic constraints on the effects of gas hydrate on sediment physical properties and fluid flow: a review. Geofluids, 3, 1-15.

[125] Zillmer, M. (2006). A method for determining gas-hydrate or free-gas saturation of porous media from seismic measurements. Geophysics, 71, 21-32.

[126] Singh, S. C., Minshull, T. A., \& Spence, G. D. (1993). Velocity structure of a gas hydrate reflector. Science, 260, 204-207.

[127] Tinivella, U. (2002). The seismic response to overpressure versus gas hydrate and free gas concentration. J Seismic Explor, 11, 283-305.

[128] Tinivella, U. (1999). A method to estimate gas hydrate and free gas concentrations in marine sediments. Bollettino di Geofisica Teorica ed Applicata, 40, 19-30.

[129] Tinivella, U., \& Carcione, M. (2001). Estimation of gas-hydrate concentration and free-gas saturation from log and seismic data. The Leading Edge, 20.

[130] Ledley, T. S., Sundquist, E. T., Schwartz, S. E., Hall, D. K., Fellows, J. D., \& Killeen, T. L. (1999). Climate Change and Greenhouse Gases. EOS, Transactions of the American Geophysical Union. 80, 453-458.

[131] Nakano, S., Moritoki, M., \& Ohgaki, K. (1998). High-Pressure Phase Equilibrium and Raman Microprobe Spectroscopic Studies on CO2 Hydrate System. J. Chem. Eng. Data; 43, 807-810.

[132] Lackner, K. S. (2003). A Guide to CO2 Sequestration. Science, 300, 1677-1678, doi: science.1079033. 
[133] Chadwick, R. A., Arts, R., \& Eiken, O. 4D seismic quantification of a growing CO2 plume at Sleipner, North Sea. Geological Society, London, Petroleum Geology Conference series, 6, 1385-1399, doi:.

[134] Conti, S., \& Fontana, D. (2011). Possible Relationships between Seep Carbonates and Gas Hydrates in the Miocene of the Northern Apennines. Journal of Geological Research, 20727, doi:10.1155/2011/920727.

[135] Liu, X., \& Flemings, P. B. (2007). Dynamic multiphase flow model of hydrate formation in marine sediments. Journal of Geophysical Research, 112: B03101, doi: 10.1029/2005JB004227.

[136] Schowalter, T. T. (1979). Mechanics of secondary hydrocarbon migration and entrapment. American Association of Petroleum Geologists Bulletin, 63, 723-760.

[137] Milkov, A. V., Claypool, G. E., Lee-J, Y., \& Sassen, R. (2005). Gas hydrate systems at Hydrate Ridge offshore Oregon inferred from molecular and isotopic properties of hydrate-bound and void gases, Geochim. Cosmochim. Acta, 69, 1007-1026.

[138] Trehu, A. M., Flemings, P. B., Bangs, N. L., Chevallier, J., Gra 'cia, E., Johnson, J. E., Liu-S, C., Liu, X., Riedel, M., \& Torres, . (2004). Feeding methane vents and gas hydrate deposits at south Hydrate Ridge. Geophys. Res. Lett., 31: L23310, doi: 10.1029/2004GL021286.

[139] Flemings, P. B., Liu, X., \& Winter, W. (2003). Critical pressure and multiphase flow in Blake Ridge gas hydrates. Geology, 31, 1057-1060.

[140] Gorman, A. R., Holbrook, W. S., Hornbach, M. J., \& Hackwith, K. L. (2002). Migration of methane gas through the hydrate stability zone in a low-flux hydrate province. Geology, 30, 327-330.

[141] Hornbach, M., Saffer, D. M., \& Holbrook, W. S. (2003). Critically pressured free-gas reservoirs below gas-hydrate provinces. Nature, 427, 142-144.

[142] Nimblett, J., \& Ruppel, C. (2003). Permeability evolution during the formation of gas hydrates in marine sediments. J. Geophys. Res., 108(B9), 2420, doi: 10.1029/2001JB001650.

[143] Bouriak, S., Vanneste, M., \& Saoutkine, A. (2000). Inferred gas hydrates and clay diapirs near the Storegga slide on the southern edge of the Voring Plateau, offshore Norway. Mar Geol, 163, 125-148.

[144] Buenz, S., \& Mienert, J. (2004). Acoustic imaging of gas hydrate and free gas at the Storegga Slide. J. Geophys. Res, 109, B04102, doi:10.1029/2003JB002863.

[145] Ginsburg, G. D., Ivanov, V. L., \& Soloviev, V. A. (1984). Natural gas hydrates of the World's Oceans. In: Oil and gas content of the World's Oceans. PGO Sevmorgeologia in Russian)., 141-158. 
[146] Ginsburg, G. D., Kremlev, A. N., Grigor'ev, M. N., Larkin, G. V., Pavlenkin, A. D., \& Saltykova, N. A. (1990). Filtrogenic gas hydrates in the Black Sea (twenty-first voyage of the research vessel Evpatoria). Sov. Geol. Geophys, 31, 8-16.

[147] Limonov, A. F., Woodside, J. M., \& Ivanov, M. K. (1994). Mud volcanism in the Mediterranean and Black Seas and shallow structure of the Eratosthenes Seamount. Initial results of the geological and geophysical investigations during the Third UNESCO-ESF "Training Through Research" Cruise of RV Gelendzhik, June-July 1993. UNESCO Rep. Mar. Sci., 64.

[148] Woodside, J. M., Ivanov, M. K., \& Limonov, A. F. (1997). Neotectonics and fluid flow through seafloor sediments in the Eastern Mediterranean and Black Seas- Parts I and II. IOC Tech. Ser., 48.

[149] Mac, Donald. R. I., Sager, W. W., \& Peccini, M. B. (2003). Gas hydrate and chemosynthetic biota in mounded bathymetry at mid-slope hydrocarbon seepsNorthern Gulf of Mexico. Marine Geology, 198, 133-158.

[150] Judd, A., Davies, G., Wilson, J., Holmes, R., Baron, G., \& Bryde, I. (1997). Contribution to atmospheric methane by natural seepages on the UK continental shelf. Mar. Geol, 137, 165-189.

[151] Lance, S., Henry, P., Le Pichon, X., Lallemant, S., Chamley, H., Rostek, F., \& Faugeres-C, J. (1998). Submersible study of mud volcanoes seaward of the Barbados accretionary wedge: sedimentology, structure and rheology. Mar. Geol, 145, 255-292.

[152] Cronin, B. T., Ivanov, M. K., Limonov, A. F., Egorov, A., Akhmanov, G. G., Akhmetjanov, A. M., \& Kozlova, E. (1997). Shipboard Scientific Party TTR-5, New discoveries of mud volcanoes on the Eastern Mediterranean Ridge. J. Geol. Soc., 154, 173-182.

[153] Murton, B. J., \& Biggs, J. (2003). Numerical modelling of mud volcanoes and their flows using constraints from the Gulf of Cadiz. Marine Geology, 195, 223-236.

[154] Soderberg, P., \& Floden, T. (1991). Pockmark developments along a deep crustal structure in the northern Stockholm Archipelago, Baltic Sea. Beitr. Meereskd, 62, 79-102.

[155] Soderberg, P., \& Floden, T. (1992). Gas seepages, gas eruptions and degassing structures in the seafloor along the Stromma tectonic lineament in the crystalline Stockholm Archipelago, east Sweden. Cont. Shelf Res., 12, 1157-1171.

[156] Cohen, H. A., \& Mc Clay, K. (1996). Sedimentation and shale tectonics of the northwestern Niger Delta front. Mar. Pet. Geol., 13, 313-328.

[157] Bouma A.H., Roberts H.H. (1990). Northern Gulf of Mexico continental slope. GeoMar. Lett., 10, 177-181.

[158] Langseth, M. G., Westbrook, G. K., \& Hobart, A. (1988). Geophysical survey of mud volcano seaward of the Barbados Ridge Complex. J. Geophys. Res., 93, 1049-1061. 
[159] Martin, J. B., Kastner, M., Henry, P., Le Pichon, X., \& Lallemant, S. (1996). Chemical and isotopic evidence for sources of fluid in a mud volcano field seaward of the Barbados accretionary wedge. J. Geophys. Res., 101, 20325-20345.

[160] Heggland, R., \& Nygaard, E. (1998). Shale intrusions and associated surface expressions-examples from Nigerian and Norwegian deepwater areas: proceedings Offshore Technology Conference. Houston, TX, 1, 111-124.

[161] Corthay, J. E. (1998). Delineation of a massive seafloor hydrocarbon seep, overpressured aquifer sands, and shallow gas reservoir, Louisiana continental slope. Proceedings Of Offshore Technology Conference.Houston, Texas, 37-56.

[162] Neurauter, T. W., \& Bryant, W. R. (1998). Gas hydrates and their association with mud diapirs/mud volcanoes on the Louisiana continental slope. Proceedings of Offshore Technology Conference, Houston, Texas, 1, 599-607.

[163] Milkov, A. V., Lee-J, Y., Borowski, W. S., Torres, Xu. W., Tomaru, H., Tre'hu, A. M., Schultheiss, P., Dickens, G. R., \& Claypool, G. E. (2004). Co-existence of gas hydrate, free gas, and brine within the regional gas hydrate stability zone at Hydrate Ridge (Oregon margin): Evidence from prolonged degassing of a pressurized core. Earth Planet. Sci. Lett., 222, 829-843.

[164] Zatsepina, O. Y., \& Buffett, B. A. (1997). Phase equilibrium of gas hydrate: Implications for the formation of hydrate in the deep sea floor. Geophys. Res. Lett., 24, 1567-1570.

[165] Tomkeieff, S. I. (1983). Dictionary of Petrology. Wiley, New York.

[166] Ben-Avraham, Z., Smith, G., Reshef, M., \& Jungslager, E. (2002). Gas hydrate and mud volcanoes on the southwest African continental margin off South Africa. Geology (Boulder), 30, 927-930.

[167] Jungslager, E. H. A. (1999). Petroleum habitats of the South Atlantic margin. Cameron NR, Bate RH, Clure VS. (ed.) The Oil and Gas Habitats of the South Atlantic, Spec. Publ. geol. Soc. Lond, 153-168.

[168] Tinivella, U., Accaino, F., \& Camerlenghi, A. (2002). Gas hydrate and free gas distribution from inversion of seismic data on the South Shetland margin (Antarctica). Mar Geophys Res, 23, 109-123.

[169] Klepeis, K., \& Lowver, L. A. (1996). Tectonics of the Antarctic-Scotia plate boundary near Elephant and Clarence Islands, West Antarctica. J. Geophys Res, 101, 20211-20231.

[170] Loreto, M. F., Tinivella, U., Accaino, F., \& Giustiniani, M. (2011). Offshore Antarctic Peninsula Gas Hydrate Reservoir Characterization by Geophysical Data Analysis. Energies, 4(11), 39-56, doi:10.3390/en4010039. 
[171] Vargas-Cordero, I., Tinivella, U., Accaino, F., Loreto, M. F., \& Fanucci, F. (2010). Thermal state and concentration of gas hydrate and free gas of Coyhaique, Chilean Margin (44³0' S). Marine and Petroleum Geology, 27, 1148-1156.

[172] Roberts, H. H. (2001). Fluid expulsion on the Northern Gulf of Mexico continental slope: mud-prone to mineral-prone responses. Paull CK, Dillon WP. (ed.) Natural gas hydrates: occurrence, distribution, and detection. AGU Monogr 124, 145-161.

[173] Roberts, H. H., Hardage, Shedd. W. W., \& Hunt, J. (2006). Seafloor reflectivity-an important seismic property for interpreting fluid/ gas expulsion geology and the presence of gas hydrate. Leading Edge, 25, 620-628.

[174] Milkov, A. V., \& Sassen, R. (2002). Economic geology of offshore gas hydrate accumulations and provinces. Marine and Petroleum Geology, 19, 1-11. 
